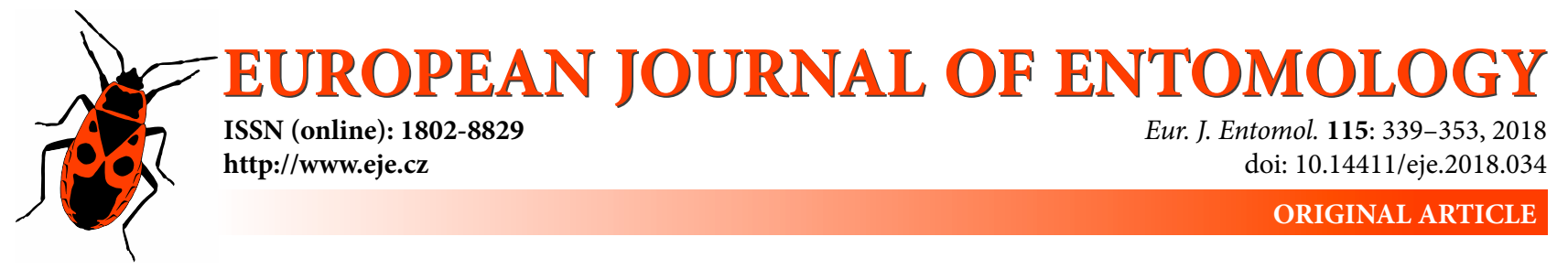

\title{
Variation in the morphology of the wings of the endangered grass-feeding butterfly Coenonympha oedippus (Lepidoptera: Nymphalidae) in response to contrasting habitats
}

\author{
Jure JUGOVIC ${ }^{1}$, Sara $_{\text {ZUPAN }}{ }^{1}$, Elena BUŽAN ${ }^{1}$ and TatJana ČELIK ${ }^{2, *}$ * \\ ${ }^{1}$ Department of Biodiversity, Faculty of Mathematics, Natural Sciences and Information Technologies, University of Primorska, \\ 6000 Koper, Slovenia; e-mail: jure.jugovic@upr.si, sara.zupan@upr.si, elena.buzan@upr.si \\ ${ }^{2}$ Research Centre of the Slovenian Academy of Sciences and Arts, Novi trg 2, 1000 Ljubljana, Slovenia; \\ e-mail: tcelik@zrc-sazu.si
}

\begin{abstract}
Key words. Lepidoptera, Nymphalidae, butterfly, Coenonympha oedippus, False Ringlet, wing, adaptation, classical morphometrics, geometric morphometrics, environmental heterogeneity
\end{abstract}

\begin{abstract}
At the southern limit of its range the endangered butterfly Coenonympha oedippus inhabits grasslands (wet, dry) that differ significantly in the abundance of its larval hostplants (wet $>$ dry) and mean annual air temperature (wet < dry). We determined the difference in the wing morphology of individuals in the two contrasting habitats to test whether and how traits associated with wing size, shape and eye like spots vary in the sexes and two ecotypes. We show that sexual dimorphism follows the same (wing size and shape, number of eyespots on forewing) or different (relative area of eyespots on hindwings) patterns in the two contrasting habitats. Irrespective of ecotype, females had larger, longer and narrower wings, and more forewing eyespots than males. Sexual dimorphism in the relative area of eyespots on hindwing was female-biased in the wet, but male-biased in the dry ecotype. Ecotype dimorphism in wing size and the relative area of eyespots on the hindwing is best explained by mean annual air temperature and abundance of host-plants. While ecotype dimorphism in wing size did not differ between sexes, neither in direction (wet > dry) or in degree, in the two sexes the relative area of eyespots on hindwing had opposite patterns (males: dry > wet; females: wet $>$ dry) and was more pronounced in males than in females. The differences in wing shape between ecotypes were detected only in the hindwings of males, with more rounded apex in the dry than in the wet ecotype. We discuss the life-history traits, behavioural strategies and selection mechanisms, which largely account for the sex- and ecotype-specific variation in wing morphology.
\end{abstract}

\section{INTRODUCTION}

Butterfly wing morphology commonly varies among species and populations and even between the two sexes. Variation in wing morphology is thought to be the result of complex interactions between genetic, epigenetic and environmental variability (Watt, 2003; Nosil, 2012). In addition to flight, the most obvious function of wings, their morphological traits, such as size, shape, colour and pattern, have a number of interacting functions including thermoregulation and intra- and interspecific communication (Shreeve et al., 2009). Specific functions of the wings are related to unique sets of wing characteristics or combinations of wing-pattern elements. For example, wing size and shape are related to flight (Srygley \& Chai, 1990; Merckx \& Van Dyck, 2006), pigmentation or degree of melanisation to thermoregulation (Van Dyck \& Wiklund, 2002), specific ventral and dorsal position of bands and eyespots to in- traspecific communication (Robertson \& Monteiro, 2005; Oliver et al., 2009), predator avoidance and evasion (Dennis et al., 1986; Ho et al., 2016). Multifunctional character of butterfly wings affects a number of fitness components.

Intraspecific variation in wing morphology is the result of variability in genetic (Hill et al., 1999) and environmental factors (Nylin, 2009; Gibbs et al., 2011). Phenotypic traits that are largely affected by environment are said to exhibit phenotypic plasticity (Pigliucci et al., 2006). Traits with high plasticity levels are more responsive to environmental changes, and are generally linked to a higher capacity to occupy different environments. Phenotypic plasticity may be triggered by a number of environmental factors during development and their interactions can result in different complex patterns. Phenotypic plasticity can be adaptive or non-adaptive depending on whether the resulting phenotype is closer or further away from the op-

\footnotetext{
* Corresponding author; e-mail: tcelik@zrc-sazu.si
} 
timal phenotype in a given environment. While adaptive plasticity increases the likelihood of persistence in a new environment and enhances fitness across multiple environments, the non-adaptive plasticity decreases the chances of adaptation to a new environment (Ghalambor et al., 2007). When the differences in morphology between populations of a single species subjected to environmental heterogeneity are merely a reflection of historical isolation in interaction with neutral genetic mechanisms (e.g. genetic drift), then neutral genetic variation in populations corresponds to morphological variation. Thus, if the latter does not reflect genetic differentiation due to historical isolation, phenotypic divergence is very likely due to adaptations to local conditions (Joyce et al., 2009).

There are several studies on the environmental factors that induce phenotypic plasticity in butterfly wing morphology. The factors are latitude (Dennis et al., 1986), altitude (Dennis et al., 1986; Bai et al., 2015), temperature (Brakefield et al., 1996; Karl \& Fischer, 2008; De Jong et al., 2010; Bowden et al., 2015), hours of sunshine (Dennis et al., 1986), rainfall (Gibbs et al., 2011), quality of larval hostplants (Kooi et al., 1996; Talloen et al., 2004, 2009), variation in predator pressure (Olofsson et al., 2010) and landscape structure (Merckx \& Van Dyck, 2006). Phenotypic plasticity may largely depend on sex with females usually exhibiting a higher degree of plasticity. Such sex differences in phenotypic plasticity vary among species in both magnitude and direction. Moreover, sex-specific plasticity varies among environmental conditions as well as along the range of specific environmental variables (Stillwell et al., 2010). It is suggested that sex-specific phenotypic plasticity underlies the process generating sexual dimorphism (Teder \& Tammaru, 2005). Sex difference in the plasticity of body size of butterflies is manly generated by a sex-specific plasticity in larval development time and growth rate (Fischer \& Fiedler, 2001; Davies \& Saccheri, 2017).

We studied inter-population differences in wing morphology in the False Ringlet, Coenonympha oedippus (Fabricius, 1787). C. oedippus is one of the most endangered species of European butterfly (Van Swaay et al., 2010) and is listed in Annexes II and IV of the Habitats Directive. False Ringlet's habitat has become very fragmented due to the on-going intensification of agriculture and/or abandonment of extensive land use. We chose to study this species in the context of phenotypic plasticity, because it is one of the few European butterfly species living in two contrasting types of habitat. Most populations inhabit semi-open wet grasslands (ordo Molinietalia, ordo Tofieldietalia), whereas the southern range populations occur in dry habitats (Čelik et al., 2015). Records of the latter populations are only for the dry abandoned grasslands (Festuco-Brometea) in Slovenia (Čelik, 2003; Čelik \& Verovnik, 2010) and in north-western Croatia (this study). In Croatia, this species inhabits only the northern part of the Istrian peninsula (Kučinić et al., 1999; Šašić, 2010). In Slovenia, this species has a disjunct distribution, occurring in the centre (wet habitats with continental climate) and the south-west- ern part (dry habitats with sub-Mediterranean climate). The two areas differ in number of populations occurring there and their densities. While only two small populations still exist in the former, the species is more widespread in the latter. However, their abundance is much lower in the south-western (cf. Verovnik et al., 2015; Rakar, 2016) than the central area (Čelik, 2015). The populations in the two types of habitat differ significantly in the species of plants used as larval host-plants. The larvae feed on Carex davalliana, C. hostiana, C. panicea, C. lasiocarpa, C. x leutzii and Molinia caerulea in wet habitats (Čelik et al., 2009 and unpubl. data) and on C. humilis and Festuca rupicola in dry habitats (Čelik et al., 2015). The populations in the two types of habitat also differ in the preferred larval/ egg-laying microlocations. The above differences in the life-history traits of the populations in the two contrasting types of habitat are considered to be a consequence of microhabitat selection and adaptation to local environmental conditions (Čelik et al., 2015). C. oedippus is protandrous and univoltine (June-July), but records of few adults in the coastal part of Slovenia (Čelik \& Verovnik, 2010) and in NE Italy (Bonelli et al., 2010) indicates the possibility of a partial second generation at the southern limit of this species range.

On the basis of wing morphology there are twelve subspecies of $C$. oedippus in the European part of this species' range (Bischof, 1968). Whether and how variability in wing morphology relates to environmental factors remains to be studied. Moreover, the False Ringlet exhibits sexual dimorphism in wing traits, however, detailed studies are still lacking. General descriptions of sex-specific wing characteristics reveal that the females have larger forewings with additional submarginal ocelli on the underside, and a larger white postdiscal band on the under-side of hindwings than the males (Higgins \& Riley, 1993; Tolman, 2001). It is possible that there are obsolete well-developed submarginal ocelli on the upper surface of the hindwings of females (Bozano, 2002).

Here we compare the morphological traits of the wings of $C$. oedippus from wet and dry habitats at the southern border of this species range (Slovenia and Croatia). We tested whether and how traits associated with wing size, shape and ocellation vary in two contrasting types of habitat. Specimens from wet and dry habitats were treated as wet and dry ecotypes, respectively. We asked: (1) which traits exhibit sex and habitat type variation; (2) whether sexual dimorphism in wing morphology differs in the two ecotypes; (3) whether the ecotype-related pattern in wing morphology differs between sexes; (4) which environmental variables explain sexual and ecotype variability in wing morphology? We hypothesized that (i) males have smaller wings than females due to the effect of protandry on male size (Fageström \& Wiklund, 1982; Pincheira-Donoso \& Hunt, 2017), and that (ii) males are more mobile and as they use patrolling as mate-locating strategy and as a consequence have shorter and broader wings than females. Such a wing shape is associated with greater dispersal ability and is more efficient for long flights (Hassall, 2015). 
Females, as the more sedentary sex, expose their ventral wing surfaces more than males. Therefore, we predicted that (iii) females have a larger number and larger eyespots on the underside of their wings. Larger and multiple submarginal eyespots on the ventral surface enable more efficient avoidance of attacks by predators (Blest, 1957; Oliver et al., 2009; Ho et al., 2016). Based on the temperature-size rule (Kingsolver \& Huey, 2008), we expected that (iv) individuals from colder wet habitats would have larger wings than those from hotter dry habitats. In the latter, larval hostplants are more exposed to drought, which may lead to lower-quality diets and maturation at a smaller size (Stillwell et al., 2010; Hirst et al., 2015). Decreased food quality may also cause decreased spot size (Kooi et al., 1996). We therefore predicted that (v) dry ecotype butterflies have smaller submarginal eyespots on the ventral surface of their wings than wet ecotype specimens. We also predicted (vi) ecotype-specific wing shape at least in the more mobile sex (males) as higher air temperatures (dry habitats) enable prolonged flights for which shorter and broader wings could be an advantage. Finally, we expected that (vii) environmental variables affect wing morphology in a sex-specific way (cf. Stilwell et al., 2010; Gibbs et al., 2012), which can result in different patterns of sexual and ecotype dimorphism in the ecotypes and sexes, respectively.

\section{MATERIAL AND METHODS}

\section{Samples}

In this study we found a total of 239 individuals (males: 187; females: 52; wet ecotype: 206; dry: 33 ) of C. oedippus. This species is endangered in Europe, therefore we used only samples available in existing collections (Slovenian Natural History Museum, Biological Institute ZRC SAZU, private butterfly collections), with no additional sampling in the field. Samples originated from all of the known localities for this species in Slovenia and Croatia (Appendix 1,2).

\section{Morphometric analyses}

We determined the difference in wing morphology using classical (CM) and geometric (GM) morphometric analysis. Images of the underside of the left forewing and hindwing of each specimen on a millimetre grid were obtained using a DSRL camera (Canon 450D) taken at a fixed angle $\left(90^{\circ}\right)$ and distance $(30 \mathrm{~cm})$. To minimize potential barrel distortion resulting from the camera's optics, we took photographs at a high resolution $(4752 \times$ 3168 pixels) in JPG format, which minimises the distortion when the animals are centred, as the distortion increase towards the edges of the objective. The same person made all the measurements in order to avoid person dependent measuring errors.

To run classical morphometric analysis we recorded 24 wing parameters (distances, surfaces, counted parameters; Fig. 1, Appendix 3) using freeware ImageJ (Abramoff et al., 2004). The parameters included parameters related to wing size (FWL1FWL6, FWH, A, HWL1-HWL6, HWS) and wing ocellation (NFW, NHW, S1-S6, S31). As the size of eyespots may be correlated with wing size we calculated an ocellation index "sums hws" (Appendix 3) of the relative area of eyespots on hindwing.

In the geometric morphometric analysis we assessed the differences in both wing shape and wing size. We collected and digitized (using TpsDIG 2.10) (Rohlf, 2006) nine landmarks on the forewing and eleven landmarks on hindwing (Fig. 1). These are

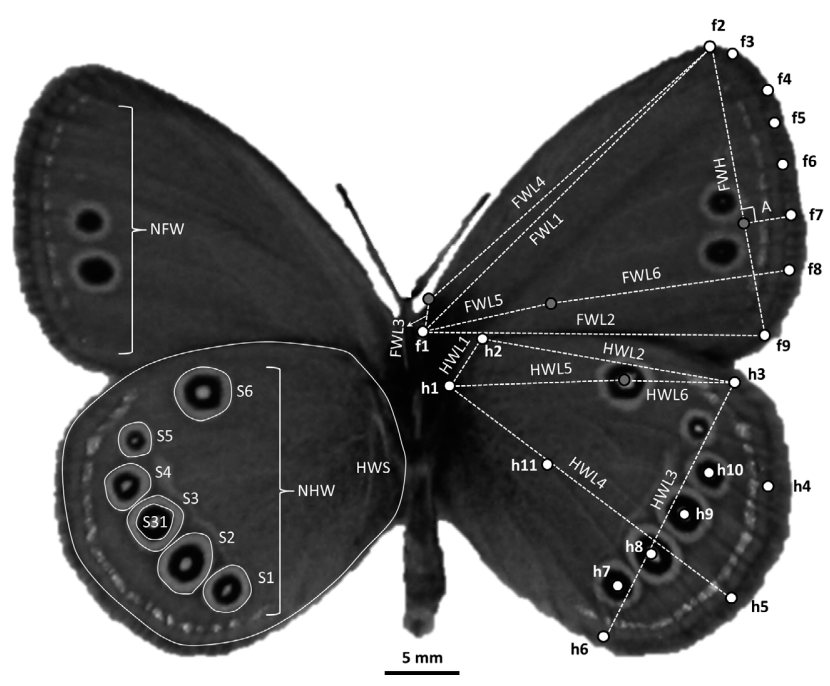

Fig. 1. Wing parameters used in the morphometric analyses of $C$. oedippus; dashed lines - distance parameters; solid lines - surface parameters; square brackets - counted parameters; white circles - landmarks for geometric morphometrics. See Appendix 3 for details.

positioned at vein terminations (f1-f9, h1, h3-h6), vein intersections (h11), wing border inflection points (h2) and eyespot' centres (h7-h10). The landmarks were transformed into $\mathrm{x}$ and $\mathrm{y}$ coordinates in Cartesian space (Adams et al., 2004). The centroid size (CS; the square root of the sum of squared distances between each landmark and the wing centroid) was used as the GM estimator of wing size. We calculated scaled CSs in freeware Coordgen6f (Sheets, 2002) (Rohlf \& Slice, 1990).

\section{Climatic data}

To identify weather conditions at the sites where specimens were collected (see Fig. 1, Appendix 2), we used data on mean annual air temperature $\left(\mathrm{T}:{ }^{\circ} \mathrm{C}\right)$, mean annual precipitation $(\mathrm{P}$ : $\mathrm{mm})$, mean annual relative air humidity ( $\mathrm{H}: \%)$ and mean duration of annual insolation (S: hours) provided by the Slovenian Environment Agency (ARSO; www.meteo.si/, www.gis.arso. gov.si/atlasokolja) for the periods 1971-2000 and 1991-2006, and from the Climate Atlas of Croatia (Zaninović et al., 2008) for the periods 1961-1990 and 1971-2000, which provided sufficiently precise and comparable data for both countries. For Slovenia, data from only one climatological station for each part of the distribution of this species was available, i.e. Ljubljana (for localities in central Slovenia: SI-LB, SI-GR, SI-ME), Bilje (for localities in the western part: SI-NG, SI-ČA, SI-MI) and Portorož (for the locality in the southwest: SI-IZ). Considering the precision of the climatological maps for Croatia (one climatological station represents a $19 \times 19 \mathrm{~km}^{2}$ block of land) and the distance between the locations sampled (Fig. 1), we used the same value of each climatic variable for all five locations in Croatia or an average value when the localities sampled were located in two different Croatian climatic zones. With only one exception (HR$\mathrm{SO})$, all the localities in wet habitats geographically experienced a continental climate (SI-LB, SI-ME, SI-GR), and all those in dry habitats geographically experienced a sub-Mediterranean climate (Appendix 1). Despite the variation in each climatic parameter during the period studied, the magnitude of difference between the wet and dry habitats for a particular parameter was always larger than its yearly variation within a habitat. In addition, it has already been shown that selection acting on the growth rate of insects is greatest at temperatures that larvae are exposed to most often during development (Kingsolver et al., 2004). Therefore, 
an average value of the temperature is an appropriate indicator of thermal conditions within a habitat when comparing size of the individuals from contrasting climates. We also applied this to other climatic parameters used in this study.

\section{Host-plants data}

The data for abundance of host-plants (HPs) in wet and dry habitats is available only for two locations in Slovenia, SI-LB (wet habitat) and SI-MI (dry habitat). As each location supported the largest $C$. oedippus population of each ecotype over the last 10 years, we considered that these populations are good indicators of the state of host-plant abundance in the wet and the dry ecotypes. Information on the abundance of known (C. humilis, F. rupicola) and potential (other grass species) larval host-plants in dry habitats (SI-MI) was retrieved from Čelik et al. (2015) for the years 2010-2012. For wet habitat (SI-LB), we used data from standard phytosociological relevés, which were carried out in the years 2001, 2013, 2014 and 2015 (Vreš \& Čelik, unpubl.). Only known host-plant species (C. davalliana, $C$. hostiana, $C$. panicea, C. lasiocarpa, C. x leutzii, M. caerulea; Čelik et al., 2009 and unpubl. data) were used for calculating the abundance of larval host-plants in wet habitats.

\section{Statistical analyses}

Data on wing size and ocellation parameters separated in terms of sex (males, females) and habitat (wet and dry ecotype) were tested for normality using the Kolmogorov-Smirnov test. All but four parameters (S31 and FWH for males from wet and dry habitats, respectively; FWL5 and FWL6 for females from wet habitats) were normally distributed, therefore we used the raw data in subsequent analyses.

We used the Independent-Sample T-tests to determine if wing and eyespot sizes differ between the sexes and between individuals from the two habitats. Each size parameter for CM and GM (CSs) was tested separately for sex and habitat. To assess the relationship between the number of eyespots and sex/habitat, Chi Square tests with a Likelihood ratio statistic were applied separately for forewing and hindwing, as well as for each habitat and sex.

To find the combination of CM parameters that best explain the sexual and ecotype dimorphism in wing size and ocellation, we used logistic regression. We used sex and ecotype as a response variable separately. All CM parameters except number of eyespots (Appendix 3) were set as predictor variables. Prior to the regression analyses, all predictors were tested for inter-correlations by calculating Pearson's $(r)$ correlation coefficients. The different sets of predictor variables entering the models were designed based on the criterion of $r<|0.7|$. Our statistical approach was to fit models corresponding to all possible combinations of the predictor variables and select the best model according to its $\mathrm{AIC}_{\mathrm{c}}$ value (Burnham \& Anderson, 2002).

Degree and direction of sexual dimorphism in wing size and ocellation were estimated for each ecotype using the Lovich \& Gibbons (1992) sexual dimorphism index (SDI), in which sexual dimorphism is quantified as (mean female size/mean male size) - 1. The SDI was calculated separately for each wing size parameter (15 WS parameters: FWL1-FWL6, FWH, A, HWL1HWL6, HWS; Appendix 3) and for each ocellation parameter (8 WO parameters: S1-S6, sums_hws; Appendix 3), and then averaged across the size/ocellation parameters used. In the same way we calculated the ecotype dimorphism index (EDI) for each sex using the adjusted formula: $\mathrm{EDI}=$ (mean size in wet habitat $/$ mean size in dry habitat) -1 . For wing ocellation, we calculated two types of SDI/EDI so that in the first type ( $\left.\mathrm{SDI}_{1}, \mathrm{EDI}_{1}\right)$ all 8 ocellation parameters were included, but in the second type $\left(\mathrm{SDI}_{2}\right.$,
$\mathrm{EDI}_{2}$ ) only the parameter sums hws. For assessing the difference in the degree of sexual/ecotype dimorphism between ecotypes/ sexes, we applied the Mann Whitney U-test for each index, except for $\mathrm{SDI}_{2}$ and $\mathrm{EDI}_{2}$, where testing was impossible as only one parameter was included in the calculation of this index.

For estimating the average degree of sex-specific and ecotypespecific plasticity in wing size and ocellation, we calculated the mean coefficient of variation $(\mathrm{CVm})$ for the same wing-size (WS) and wing-ocellation (WO) parameters as in the calculation of SDI/EDI, separately for each sex within each ecotype. We applied the formula: $\mathrm{CVm}=\Sigma \mathrm{CV} / \mathrm{n}$, where $\mathrm{CV}$ denotes the coefficient of variation for each parameter $(\mathrm{CV}=\mathrm{SD} /$ mean $)$ and $n$ equals a number of parameters in WS/WO. For wing ocellation, we calculated two types of $\mathrm{CVm}$, in which the first type $\left(\mathrm{CVm}_{1}\right)$ included all 8 ocellation parameters and the second type $\left(\mathrm{CVm}_{2}\right)$ only sums_hws. We used the Mann Whitney U-test for assessing the difference in average degree of plasticity between sexes/ ecotypes. For $\mathrm{CVm}_{2}$, testing for a difference was impossible as only one parameter was included in the calculation of $\mathrm{CVm}$.

To evaluate the climatic and host-plant differences between wet and dry habitats, we applied Independent-Sample T-tests and Mann-Whitney U-tests, respectively. Then, we tested the effect of environmental variables (T, P, H, S, HPs), sex, and interactions between environmental variables and sex on wing size and ocellation using Generalised Linear Model (GLM) analyses. We selected the five CM parameters most representative of wing length, width and ocellation (FWL2, HWL4, FWH, HWL3, sums_hws), and each of them was treated as a response variable in GLMs. Sex and HPs (using median value for wet and dry habitats, respectively) were added as fixed factors and climatic variables as covariates. For each response variable, we used two types [marked as (a) and (b)] of GLMs because of the strong inter-correlations (Kendall's tau-b $>|0.7|$ ) between environmental predictors. As HPs were treated as a factor, it was consequently also a predictor for ecotype. Again, we selected the best model and supporting models based on a $\triangle \mathrm{AIC}_{\mathrm{c}}$ value $<2$.

Aiming to reduce the dimensionality of the GM data (20 landmark parameters) we used principal component analysis (PCA) to explore if sexes/ecotypes differ in wing shape along two dimensions (PC1, PC2). PCA was carried out separately for forewings and hindwings. Major shape changes from centroid values along principal axes in PCA in projected view were illustrated using wireframe graphs (Bookstein, 1989). One-way MANOVA of the first two principal components (PC1, PC2) as dependent variables was used to test the effect of habitat (within each sex) and sex (within each ecotype) on wing shape using ecotype and sex as a fixed factor, respectively.

Statistical analyses were performed using IBM SPSS STATISTICS Version 22, PAST (Hammer et al., 2001) and MorphoJ 1.01b (Klingenberg, 2011).

\section{RESULTS}

\section{Sexual dimorphism}

The differences in wing morphology, wing size and ocellation associated with sex are given in Tables 1 and 2. In summary, females from the wet ecotype have longer (FWL4, A) and narrower (FWH) forewings, longer hindwings (HWL2, HWL4) and relatively larger areas of eyespots on their hindwings (sums_hws) than males (Table 1). Accordingly, the GM revealed that females have larger wings than males (CS: $p<0.001$; Table 2). Further, females from wet habitats have more eyespots on both wings (NFW: $\mathrm{p}<0.001$; NHW: $\mathrm{p}<0.01$; Table 2). 
In the dry habitat, the black spot in eyespot 3 (S31) is larger in females (Table 1) and the number of eyespots on the forewing is greater than in males (NFW: $p<0.001$; Table 2). The GM analysis indicates that females have slightly larger forewings than males, however, we found no significant differences in the hindwing sizes of the sexes (CS: NS; Table 2).

Female-biased sexual dimorphism in wing size was detected in both ecotypes (Table 3: positive values of SDI). This sexual dimorphism is more pronounced in the wet than the dry ecotype (Table 3: $p<0.05$ ). Similarly, there is a female-biased sexual dimorphism in size of hindwing eyespots in both ecotypes (Table 3: positive values of SDI $)$, which is more pronounced in the wet ecotype (Table 3: $p=0.059$ ). The direction of sexual dimorphism in the conspicuousness of hindwing eyespots $\left(\mathrm{SDI}_{2}\right)$ differed between the ecotypes. The latter was female-biased in the wet, but male-biased in the dry ecotype (Table 3; value of $\mathrm{SDI}_{2}$ : wet - positive, dry - negative). The higher absolute $\mathrm{SDI}_{2}$ value in the wet ecotype indicates that sexual dimorphism in conspicuousness of hindwing eyespots is more expressed in the wet ecotype corroborating the results of univariate comparisons between sexes for sums
Table 1. Results of the logistic regression analysis of the sexual dimorphism in the wing morphology of $C$. oedippus from (a) wet and (b) dry habitats. Dependent variable: female $=0$, male $=1$. Only the best models for (a) and (b) are shown.

\begin{tabular}{lrrrrr}
\hline Parameter & Coefficient & SE & $\begin{array}{c}\text { Wald } \\
\text { statistic }\end{array}$ & $p$ & $\begin{array}{l}\text { Odds } \\
\text { ratio }\end{array}$ \\
\hline (a) WET ecotype ${ }^{+}$ & & & & & \\
FWL4 & -1.616 & 0.444 & 13.247 & 0.000 & 0.199 \\
FWH & 2.381 & 0.683 & 12.172 & 0.000 & 10.820 \\
A & -2.456 & 1.061 & 5.355 & 0.021 & 0.086 \\
HWL2 & -0.895 & 0.363 & 6.075 & 0.014 & 0.409 \\
HWL4 & -1.532 & 0.535 & 8.209 & 0.004 & 0.216 \\
S6 & 0.932 & 0.348 & 7.173 & 0.007 & 2.540 \\
Sums_hws & -55.983 & 15.475 & 13.088 & 0.000 & 0.000 \\
Constant & 43.557 & 9.800 & 19.756 & 0.000 & $8.25+18$
\end{tabular}

Model $X^{2}=112.2, \mathrm{df}=7, \mathrm{p}<0.0001$, Nagelkerke $R^{2}=0.719$, correctly classified $92.2 \%$ (female: $81.4 \%$, male: $96.0 \%$ ).

\begin{tabular}{lrrrrr}
\hline (b) DRY ecotype ${ }^{\ddagger}$ & & & & & \\
S31 & -16.197 & 7.518 & 4.642 & 0.031 & 0 \\
Constant & 3.582 & 1.454 & 6.069 & 0.014 & 35.956
\end{tabular}

Model $X^{2}=6.1, \mathrm{df}=1, \mathrm{p}<0.05$, Nagelkerke $\mathrm{R}^{2}=0.291$, correctly classified $84.6 \%$ (female: $62.5 \%$, male: $94.4 \%$ ).

+ Variables entered into the regression analysis: FWL3, FWL4, FWL 5, FWL6, FWH, A, HWL1, HWL2, HWL3, HWL4, HWL6, S5, S6, S31, sums hws. $\neq$ Variables entered into the regression analysis: HWL1, HWL5, S31, sums hws.

Table 2. Sexual and ecotype differences in wing size and ocellation in C. oedippus. For each parameter, a significant difference between the sexes/ecotypes is denoted by asterisks $\left({ }^{* * *} p<0.001,{ }^{* *} p<0.01,{ }^{*} p<0.05\right)$ or NS (not significant). Mean values for all parameters are presented, except for the number of eyespots (NFW, NHW), which are presented as frequencies. NE - number of eyespots.

\begin{tabular}{|c|c|c|c|c|c|c|c|c|c|}
\hline \multirow{3}{*}{ Parameter } & \multirow{3}{*}{ NE } & \multicolumn{4}{|c|}{ Parameter value } & \multicolumn{2}{|c|}{ Sexual differences } & \multicolumn{2}{|c|}{ Ecotype differences } \\
\hline & & \multicolumn{2}{|c|}{ Wet habitat } & \multicolumn{2}{|c|}{ Dry habitat } & \multirow{2}{*}{$\begin{array}{c}\text { Wet } \\
p\end{array}$} & \multirow{2}{*}{$\begin{array}{c}\text { Dry } \\
p\end{array}$} & \multirow{2}{*}{$\frac{\text { Males }}{p}$} & \multirow{2}{*}{$\begin{array}{c}\text { Females } \\
\mathrm{p}\end{array}$} \\
\hline & & $\begin{array}{c}\text { Males } \\
(N=124)\end{array}$ & $\begin{array}{l}\text { Females } \\
(\mathrm{N}=43)\end{array}$ & $\begin{array}{c}\text { Males } \\
(\mathrm{N}=18)\end{array}$ & $\begin{array}{c}\text { Females } \\
(\mathrm{N}=8)\end{array}$ & & & & \\
\hline FWL1 & & 18.72 & 19.76 & 17.96 & 18.45 & $* \star *$ & NS & ** & $* *$ \\
\hline FWL2 & & 14.15 & 15.38 & 13.17 & 13.63 & $* * *$ & NS & $* *$ & $* \star *$ \\
\hline FWL3 & & 2.92 & 2.58 & 2.35 & 2.45 & $* *$ & NS & $* *$ & NS \\
\hline FWL4 & & 16.68 & 18.07 & 16.42 & 16.84 & $* * *$ & NS & NS & $* *$ \\
\hline FWL5 & & 6.04 & 6.49 & 5.36 & 5.36 & $* *$ & NS & $\star \star \star *$ & $* *$ \\
\hline FWL6 & & 10.29 & 11.16 & 10.28 & 10.9 & $* * *$ & NS & NS & NS \\
\hline $\mathrm{FWH}$ & & 12.49 & 12.55 & 11.72 & 12.2 & NS & NS & NS & NS \\
\hline A & & 2.37 & 2.57 & 2.58 & 2.58 & $* *$ & NS & NS & NS \\
\hline \multirow[t]{6}{*}{ NFW } & 0 & 9 & 0 & 2 & 0 & $* * *$ & $* * *$ & NS & NS \\
\hline & 1 & 12 & 0 & 3 & 0 & & & & \\
\hline & 2 & 34 & 0 & 5 & 0 & & & & \\
\hline & 3 & 59 & 8 & 8 & 2 & & & & \\
\hline & 4 & 9 & 22 & 0 & 4 & & & & \\
\hline & 5 & 1 & 13 & 0 & 2 & & & & \\
\hline HWL1 & & 3.66 & 3.54 & 3 & 3.35 & NS & NS & $* * *$ & NS \\
\hline HWL2 & & 11.34 & 12.42 & 11.48 & 11.3 & $* * *$ & NS & NS & $* *$ \\
\hline HWL3 & & 12.45 & 12.82 & 11.88 & 12.14 & $* * *$ & NS & $\star \star * *$ & ** \\
\hline HWL4 & & 15.21 & 16.51 & 14.79 & 15.4 & $* * *$ & NS & $*$ & $* *$ \\
\hline HWL5 & & 9.22 & 9.83 & 8.77 & 8.75 & $* * *$ & NS & $* *$ & $* * *$ \\
\hline HWL6 & & 4.01 & 4.5 & 4.08 & 4.34 & $* * *$ & NS & NS & NS \\
\hline HWS & & 160.14 & 176.84 & 148.63 & 157.61 & $* * *$ & NS & $* * *$ & $* *$ \\
\hline S1 & & 2.98 & 3.64 & 3.32 & 2.81 & $* * *$ & NS & NS & * \\
\hline S2 & & 4.87 & 5.92 & 5.23 & 5.27 & $\star * *$ & NS & NS & NS \\
\hline S3 & & 4.39 & 5.63 & 4.51 & 4.82 & $* * *$ & NS & NS & * \\
\hline S31 & & 0.2 & 0.24 & 0.13 & 0.21 & NS & $*$ & NS & NS \\
\hline S4 & & 2.79 & 3.65 & 3.08 & 3.2 & $* \star *$ & NS & NS & NS \\
\hline S5 & & 1.15 & 1.82 & 1.24 & 1.87 & 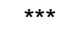 & NS & NS & NS \\
\hline S6 & & 4.31 & 4.86 & 4.74 & 4.62 & * & NS & NS & NS \\
\hline \multirow{2}{*}{ NHW } & 5 & 28 & 2 & 1 & 1 & ** & NS & NS & NS \\
\hline & 6 & 96 & 41 & 17 & 7 & & & & \\
\hline sums_hws & & 0.13 & 0.14 & 0.15 & 0.14 & $* * *$ & NS & $* *$ & NS \\
\hline CS forewing & & 20.48 & 21.61 & 19.46 & 20.44 & $\star \star \star *$ & * & $* * *$ & ** \\
\hline CS hindwing & & 20.47 & 21.61 & 19.51 & 20.25 & $* * *$ & NS & $* * *$ & $* \star * *$ \\
\hline
\end{tabular}


hws (Table 2). We found no significant differences in the average degree of plasticity, neither for wing size (Table 3: $\mathrm{CV}_{\mathrm{m}}$ ) nor for wing occelation in the sexes (Table 3: $\mathrm{CVm}_{1}$ ).

The GM analysis indicates that sex has a multivariate main effect on both forewing (Wilks' $\lambda=0.814, \mathrm{~F}_{(2,136)}=$ $15.58, \mathrm{p}<0.001$ ) and hindwing shape (Wilks' $\lambda=0.676$, $\left.\mathrm{F}_{(2,126)}=30.15, \mathrm{p}<0.001\right)$ in the wet ecotype. For the forewing, $\mathrm{PC} 1$ describing the wing width and $\mathrm{PC} 2$ reflecting the changes in roundness of the outer wing margin (position of landmarks f2-f9, Figs 1, 2a) accounted for $41 \%$ and $22 \%$ of the total variance, respectively (Fig. 2a). Significant difference in PC1 scores implies that females have (on average) narrower wings than males (ANOVA effect: $F_{(1}$, $\left.{ }_{138)}=31.37, \mathrm{p}<0.001\right)$. However, the sexes do not differ significantly in PC2 scores (ANOVA effect: $\mathrm{F}_{(1,138)}=0.01$, $\mathrm{p}>0.05)$. For the hindwing, $\mathrm{PC} 1$ and $\mathrm{PC} 2$ accounted for $25 \%$ and $16 \%$ of the total variance, respectively (Fig. $2 \mathrm{c}$ ). The extreme values of PC1 were recorded for females with the most elongated and narrow wings (the highest PC1 scores) and males with the shortest and widest wings (the lowest PC1 scores). The difference in PC1 scores between sexes was significant (ANOVA effect: $F_{(1,128)}=20.72$, $p<$ $0.001)$. Considering the changes in the positions of landmarks h3-h6 (Fig. 1) along PC2 (Fig. 2c), this axis basically describes the shape of the outer wing margin, which is more convex in females (ANOVA effect: $\mathrm{F}_{(1,128)}=28.52$, $\mathrm{p}<0.001)$.

In the dry ecotype, there was sexual dimorphism in wing shape for both the forewing (Wilks' $\lambda=0.804, \mathrm{~F}_{(2,29)}=$ $3.53, \mathrm{p}<0.05$ ) and hindwing (Wilks' $\lambda=0.556, \mathrm{~F}_{(2,30)}=$ $11.98, \mathrm{p}<0.001)$. For the forewing, PC1 and PC2 account for $32 \%$ and $23 \%$ of the total variance, respectively (Fig. 2b). The differences in forewing shape between the sexes were not significant along the first PC axis (ANOVA effect: $\left.F_{(1,31)}=0.45, p>0.05\right)$. PC2 scores reflect significant changes in roundness of the outer wing margin and a narrowing of the wing (ANOVA effect: $\mathrm{F}_{(1,31)}=6.64, \mathrm{p}<$ $0.05)$. This indicates more convex and narrower forewings in females (Fig. 1, 2b). For the hindwing, PC1 and PC2 account for $33 \%$ and $21 \%$ of the total variance, respectively (Fig. 2d). Significant differences between sexes are only indicated along PC1 (ANOVA effect - PC1: $\mathrm{F}_{(1,32)}=18.48$, $\left.\mathrm{p}<0.001 ; \mathrm{PC} 2: \mathrm{F}_{(1,32)}=2.35, \mathrm{p}>0.05\right)$, again suggesting narrower and longer hindwings in females.

\section{Ecotype differences}

Ecotype differences in wing morphology were best explained by wing length. Irrespective of sex, individuals from wet habitats had longer wings than those from the dry habitats (Tables 2 and 4). This pattern was revealed also by the GM analysis: the centroid sizes of both wings of males and females from wet habitats were larger (Table 2). In males, there are additional ecotype differences: the black spot in eyespot 3 in males from the wet ecotype is larger (S31) and they have a relatively smaller area of eyespots on the hindwing (sums_hws) (Tables 2 and 4). In both sexes, there was no association between number of eyespots and habitat (Table 2).
Table 3. Degree and direction of sexual/ecotype dimorphism and average degree of plasticity in wing size (WS) and ocellation (WO) in C. oedippus, quantified by the sexual/ecotype dimorphism index (SDI/EDI) and mean coefficient of variation ( $\mathrm{CVm}$; in percentage), respectively. The differences in degree of sexual/ecotype dimorphism and degree of plasticity between sexes/ecotypes were tested for all indices, except $\mathrm{SDI}_{2}, \mathrm{EDI}_{2}$ and $\mathrm{CVm}_{2}$, using MannWhitney U-test. A significant difference is denoted by an asterisk ( ${ }^{*} p<0.05$ ) or NS (not significant). Testing of differences was not possible for $\mathrm{SDI}_{2}, \mathrm{EDI}_{2}, \mathrm{CVm}_{2}$, as only one parameter (sums_hws) was used for calculating these indices. For $\mathrm{SDI}_{1}, \mathrm{EDI}_{1}, \mathrm{CVm} \overline{\mathrm{m}}_{1}$, all eight WO parameters (S1, S2, S3, S31, S4, S5, S6, sums_hws) were included in the calculation of these indices.

\begin{tabular}{|c|c|c|c|c|}
\hline $\begin{array}{c}\text { Type of wing } \\
\text { traits }\end{array}$ & Index & Group tested & $\begin{array}{l}\text { Index } \\
\text { value }\end{array}$ & $\mathrm{p}$ \\
\hline \multirow[t]{2}{*}{ WS } & \multirow[t]{2}{*}{ SDI } & Wet ecotype & 0.083 & \multirow[t]{2}{*}{ * } \\
\hline & & Dry ecotype & 0.035 & \\
\hline \multirow[t]{4}{*}{ WO } & \multirow[t]{2}{*}{$\mathrm{SDI}_{1}$} & Wet ecotype & 0.218 & \multirow{4}{*}{ NS $(p=0.059)$} \\
\hline & & Dry ecotype & 0.023 & \\
\hline & \multirow[t]{2}{*}{$\mathrm{SDI}_{2}$} & Wet ecotype & 0.130 & \\
\hline & & Dry ecotype & -0.046 & \\
\hline \multirow[t]{2}{*}{ WS } & \multirow[t]{2}{*}{ EDI } & Males & 0.048 & \multirow[t]{2}{*}{ NS } \\
\hline & & Females & 0.071 & \\
\hline \multirow[t]{4}{*}{ WO } & \multirow[t]{2}{*}{$\mathrm{EDI}_{1}$} & Males & -0.082 & \multirow[t]{4}{*}{ * } \\
\hline & & Females & 0.133 & \\
\hline & \multirow[t]{2}{*}{$\mathrm{EDI}_{2}$} & Males & -0.147 & \\
\hline & & Females & 0.010 & \\
\hline \multirow[t]{4}{*}{ WS } & \multirow[t]{4}{*}{$\mathrm{CVm}$} & Males, wet ecotype & 9.8 & \multirow[t]{4}{*}{$\mathrm{NS}^{\#}$} \\
\hline & & Females, wet ecotype & 9.7 & \\
\hline & & Males, dry ecotype & 11.7 & \\
\hline & & Females, dry ecotype & 10.1 & \\
\hline \multirow[t]{8}{*}{ WO } & \multirow[t]{4}{*}{$\mathrm{CVm}_{1}$} & Males, wet ecotype & 38.4 & \multirow[t]{8}{*}{$\mathrm{NS}^{\#}$} \\
\hline & & Females, wet ecotype & 24.8 & \\
\hline & & Males, dry ecotype & 29.1 & \\
\hline & & Females, dry ecotype & 30.4 & \\
\hline & \multirow[t]{4}{*}{$\mathrm{CVm}_{2}$} & Males, wet ecotype & 21.1 & \\
\hline & & Females, wet ecotype & 17.4 & \\
\hline & & Males, dry ecotype & 21.5 & \\
\hline & & Females, dry ecotype & 18.5 & \\
\hline
\end{tabular}

\# Significance for all pairwise comparisons, i.e. within sex/ecotype.

Ecotype dimorphism in wing size did not differ between sexes, neither in direction (Table 3: positive values of EDI, i.e. wet $>$ dry) or degree (Table 3: NS). A difference between sexes was detected in the direction of ecotype dimorphism for both, the absolute $\left(\mathrm{EDI}_{1}\right)$ and relative size of eyespots on the hindwing ( $\left.\mathrm{EDI}_{2}\right)$. In males, individuals from the dry habitat have larger and more conspicuous eyespots than those from the wet habitat (Table 3: negative values of EDI ${ }_{1}$ and $\mathrm{EDI}_{2}$ ), but an opposite pattern was recorded in females (Table 3: positive values of EDI and $\mathrm{EDI}_{2}$ ). Ecotype dimorphism in absolute size of the eyespots on the hindwing $\left(\mathrm{EDI}_{1}\right)$ was more pronounced in females (Table 3: $p<0.05$ ), but a higher absolute value of $\mathrm{EDI}_{2}$ in males compared to females indicates that ecotype dimorphism in conspicuousness of hindwing eyespots was more expressed in males. This is in agreement with the results of the univariate comparisons between ecotypes for sums hws (Table 2). The average degree of plasticity did not differ significantly between ecotypes, neither for wing size (Table 3: $\mathrm{CV}_{\mathrm{m}}$ ) or wing ocellation (Table 3: $\mathrm{CVm}_{1}$ ).

Based on the PCA of geometric landmarks (Fig. 3) there are no prominent differences between wing shape in the 


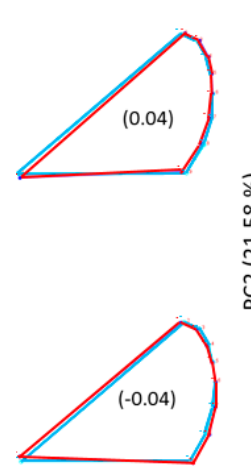

Forewing
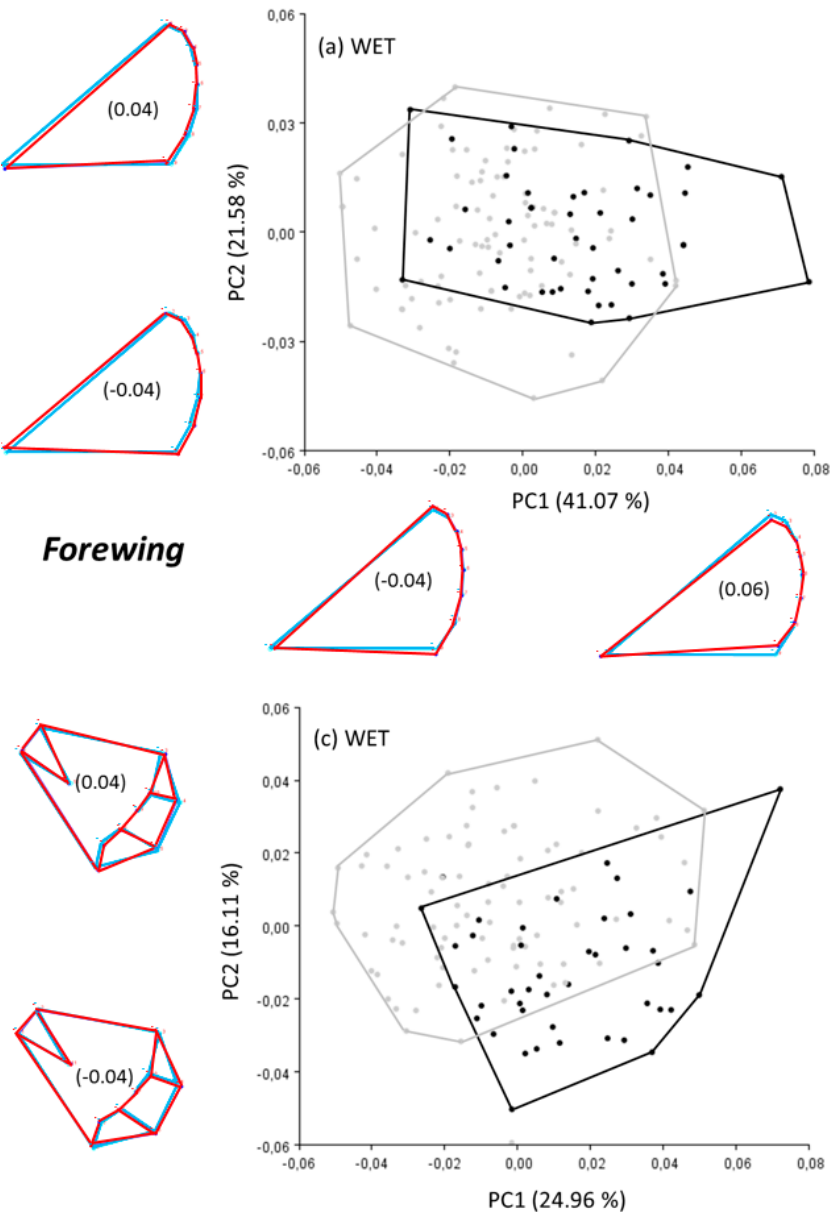

Hindwing
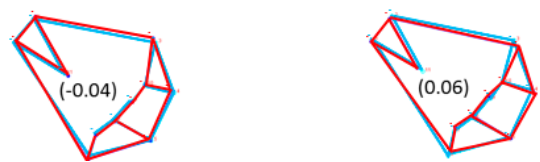
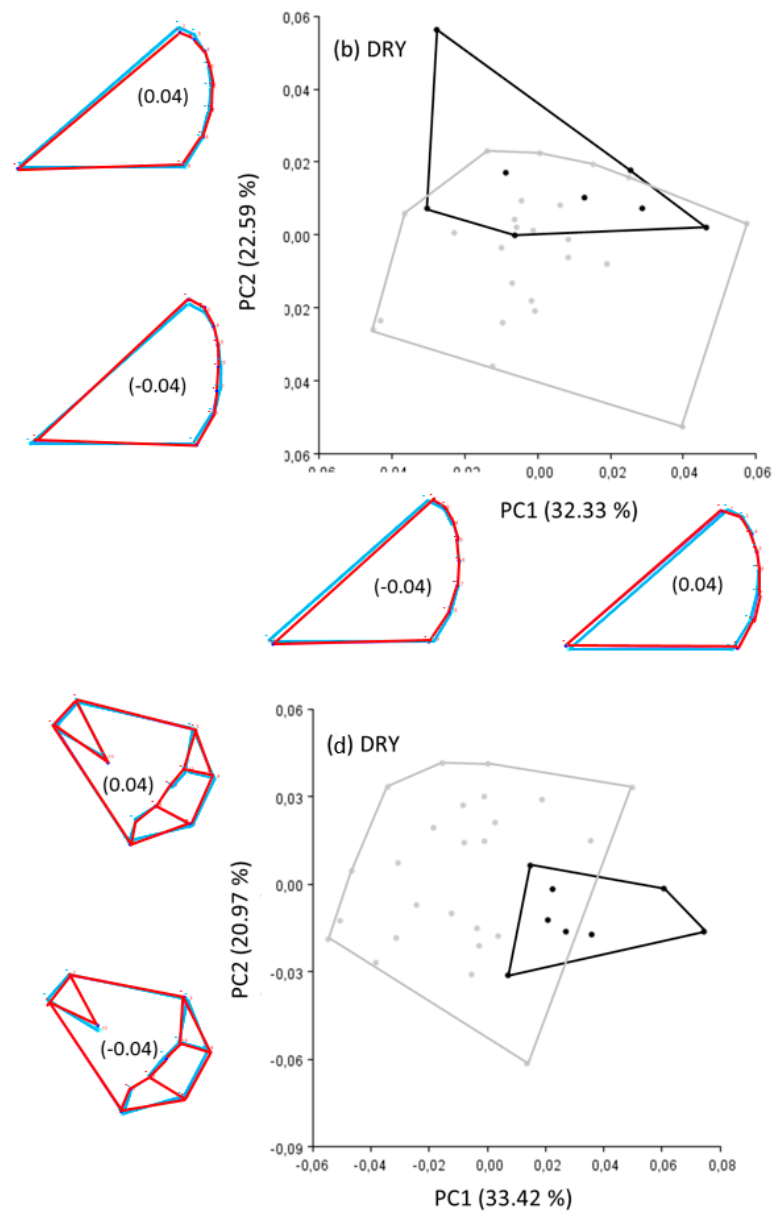

- MALES

- females
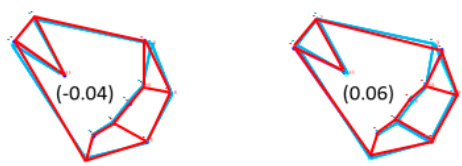

Fig. 2. Principal component analysis of sexual dimorphism in wing shape parameters obtained using geometric morphometry of $C$. oedippus specimens from wet and dry habitats: (a) wet-habitat forewing, (b) dry-habitat forewing, (c) wet-habitat hindwing, (d) dry-habitat hindwing. Deviations from centroid shape (blue) are denoted by red wireframe graphs along PC axes at given values (in brackets within each wireframe). Percentage of explained variance is added in brackets for each PC axis.

two ecotypes. For the forewings, $\mathrm{PC} 1$ and $\mathrm{PC} 2$ account for $31 \%$ and $27 \%$ of total variance, respectively, in males, and $43 \%$ and $21 \%$ of total variance, respectively, in females. We found no ecotype difference in forewing shape (males: Wilks' $\lambda=0.985, \mathrm{~F}_{(2,114)}=0.41, \mathrm{p}>0.05$; females: Wilks' $\left.\lambda=0.984, \mathrm{~F}_{(2,51)}=0.67, \mathrm{p}>0.05\right)$. For hindwings, $\mathrm{PC} 1$ and PC2 account for $25 \%$ and $17 \%$ of total variance, respectively, in males, and $25 \%$ and $16 \%$ of total variance, respectively, in females. There is a significant multivariate main effect for ecotype in hindwings of males (Wilks' $\lambda=$ $0.889, \mathrm{~F}_{(2.109)}=2.11, \mathrm{p}<0.01$ ) but not females (Wilks' $\lambda$ $\left.=0.973, \mathrm{~F}_{(2,47)}=0.53, \mathrm{p}>0.05\right)$. In males, significant differences between ecotypes are recorded only along PC1 (ANOVA effect - PC1: $\mathrm{F}_{(1,11)}=11.17, \mathrm{p}<0.01 ; \mathrm{PC} 2$ : $\mathrm{F}_{(1,}$ 111) $=2.14, \mathrm{p}>0.05)$, which indicates that males from the dry ecotype have a more convex outer wing margin and more rounded apex than males from wet habitats (Fig. 3c).

\section{Effects of environmental parameters on wing size and ocellation}

Wet and dry habitats of $C$. oedippus differ significantly in mean annual air temperature $\left(\mathrm{p}<0.001\right.$; wet: $11.02^{\circ} \mathrm{C}$, dry: $\left.12.45^{\circ} \mathrm{C}\right)$ and mean annual insolation duration $(\mathrm{p}<$ 0.001; wet: $1947 \mathrm{~h}$, dry: $2170 \mathrm{~h}$ ). There was no difference in mean annual precipitation ( $p>0.8$; wet: $1341 \mathrm{~mm}$, dry: $1336 \mathrm{~mm})$ or mean annual relative air humidity $(\mathrm{p}>0.1$; wet: $59 \%$, dry: $57 \%$ ).

Abundance of known larval host-plants was significantly higher in wet compared to dry habitats of $C$. oedippus (median, wet $=71$, dry $=18$; Mann-Whitney $Z=-7.55, p<$ 0.001 ). Taking into account the potential host-plant species, i.e. several further species of grass in dry habitats, the difference in host-plant coverage between wet and dry (median $=41$ ) habitats remains significant (Mann-Whitney $\mathrm{Z}=-5.97, \mathrm{p}<0.001)$.

Wing size and ocellation are correlated with some of these environmental factors (results given in Table 5). The 
Table 4. Results of the logistic regression analysis of the ecotype differences in wing morphology of (a) males and (b) females of C. oedippus. Dependent variable: wet $=1$; dry $=2$. Only the best models for (a) and (b) are shown.

\begin{tabular}{lrrrrr}
\hline Parameter & Coefficient & SE & $\begin{array}{c}\text { Wald } \\
\text { statistic }\end{array}$ & $p$ & \multicolumn{1}{c}{$\begin{array}{l}\text { Odds } \\
\text { ratio }\end{array}$} \\
\hline (a) Males + & & & & & \\
FWL2 & -1.774 & 0.615 & 8.313 & 0.004 & 0.170 \\
FWL4 & 1.306 & 0.577 & 5.134 & 0.023 & 3.693 \\
FWL5 & -1.661 & 0.614 & 7.327 & 0.007 & 0.190 \\
HWL2 & 3.163 & 1.212 & 6.815 & 0.009 & 23.650 \\
HWL5 & -2.638 & 1.160 & 5.167 & 0.023 & 0.072 \\
HWL6 & -2.658 & 1.266 & 4.410 & 0.036 & 0.070 \\
S31 & -20.286 & 7.799 & 6.766 & 0.009 & 0.000 \\
sums_hws & 56.626 & 18.159 & 9.724 & 0.002 & $3.91+24$ \\
Constant & 3.567 & 8.925 & 0.160 & 0.689 & 35.404
\end{tabular}

Model $X^{2}=56.959, \mathrm{df}=8, \mathrm{p}<0.0001$, Nagelkerke $\mathrm{R}^{2}=0.621$, correctly classified $93.7 \%$ (wet: $98.4 \%$, dry: $61.1 \%$ ).

\begin{tabular}{lrrrrr}
\hline (b) Females ${ }^{*}$ & & & & & \\
FWL2 & -5.052 & 2.080 & 5.902 & 0.015 & 0.006 \\
FWL6 & 4.985 & 2.196 & 5.153 & 0.023 & 146.155 \\
HWL2 & -1.503 & 0.868 & 2.999 & 0.083 & 0.222 \\
Constant & 34.006 & 14.314 & 5.644 & 0.018 & $5.87+14$
\end{tabular}

Model $X^{2}=28.354, d f=3, p<0.0001$, Nagelkerke $R^{2}=0.735$ correctly classified $92.2 \%$ (wet: $93.0 \%$, dry: $87.5 \%$ ).

t Variables entered into the regression analysis: FWL2, FWL3, FWL4, FWL5, FWL6, FWH, A, HWL1, HWL2, HWL5, HWL6, HWS, S31, S5, sums_hws. $\neq$ Variables entered into the regression analysis: FWL2, FWL5, FWL6, FWH, HWL2, sums_hws.

forewing length (FWL2) correlates negatively with mean annual temperature $(\mathrm{T})$ and precipitation $(\mathrm{P})$ (Table 5: I). Females and individuals from habitats with a higher abundance of hostplants (wet ecotype) had longer forewings. The forewing width (FWH) decreased with T, and was larger for individuals from habitats with a higher abundance of hostplants (Table 5: II). The hindwing length (HWL4) and width (HWL3) were both affected by the same predictors: T, abundance of hostplants and sex (Table 5: III, IV). Hindwing size decreased with $\mathrm{T}$, and was larger for females and for individuals from habitats with higher abundance of hostplants. Non-significant interactions between sex and environmental variables $(\mathrm{T}$, abundance of hostplants) indicate that each environmental variable had the same effect on hindwing size in both sexes.

The relative area of eyespots on the hindwing (sums hws) is associated with T, abundance of hostplants (HPs), sex and interaction between sex and environmental variables (Table 5: V). Relative area of eyespots increases with T. It is larger for females than for males and for individuals from dry habitats (low HPs) than for those from wet habitats (high HPs). In addition, the mean annual air temperature has less effect on the area of eyespots in females than in males, which is reflected in a smaller difference in the area of eyespots between females than between males from contrasting habitats. This corroborates the above finding that ecotype dimorphism in the conspicuousness of the eyespots on the hindwing $\left(\mathrm{EDI}_{2}\right)$ is more expressed in males than females (Table 3: absolute value of $\mathrm{EDI}_{2}$ higher in males). The interaction between sex and HPs close to significance also indicates that an abundance of host-plants could have a different influence on the relative area of eye- spots in females than in males. As HPs is also an indicator of ecotype, an almost significant interaction with sex is reflected in a significant ecotype difference in the area of eyespots in males but not in females (Table 2). Consequently, a sexual dimorphism in the area of eyespots is significant in the wet ecotype (larger area in females) but non-significant in the dry ecotype where the area of eyespots in females almost reaches that in males (Table 2).

\section{DISCUSSION}

We compared the morphologic traits of wings of individuals of $C$. oedippus from wet and dry habitats. Specifically, we tested for sex differences potentially resulting from adaptation to variable environments. We showed that sexual dimorphism followed the same (wing size, wing shape and number of eyespots on forewings) or different (relative area of eyespots on hindwings) patterns in these two contrasting habitats. Hence, irrespective of habitat, females had larger, longer and narrower wings and more eyespots on their forewings than males. While females from the wet habitat have larger relative areas of eyespots on their hindwings compared to males, the reverse occurs in the dry habitat. There are significant associations between the sizes of the wings and eyespots and mean annual air temperature and abundance of hostplants. Individuals from the wet habitat (lower T, more hostplants) have larger wings than individuals from the dry habitats. The relative area of eyespots on the hindwings is also ecotype dimorphic with the reverse pattern in the two sexes. While males from the dry ecotype have larger areas of eyespots compared to those from the wet ecotype, the reverse ecotype dimorphism occurs in females. Ecotype dimorphism in wing shape occurs only in males with those from the dry ecotype having a more rounded apex to their hindwings than males from the wet ecotype. These two ecotypes of $C$. oedippus do not differ in the number of eyespots.

\section{Wing size}

Female-biased sexual dimorphism in wing size occurs in both ecotypes. This corroborates the female-biased sexual dimorphism recorded in a number of ectothermic species (Fairbairn, 1997), including insects (Teder \& Tammaru, 2005; Stillwell et al., 2010). This phenomenon can be largely explained by sex-specific life history patterns. Female-biased sexual size dimorphism is mainly driven by selection favouring high fecundity (Shine, 1988). This explanation is based on the correlation between female body size and fecundity; large female body size provides a larger space to accommodate eggs and/or offspring. The other important selective pressures include sexual selection via negative directional selection on male size through earlier maturation (Pincheira-Donoso \& Hunt, 2017), where earlier maturing males have a mating advantage. As $C$. oedippus is protandrous, it is very likely that sexual selection favouring earlier male eclosion (i.e. to maximise the number of matings) may at least partly explain the smaller wing-size in males compared to females. In addition, females (the larger sex) actively fly carrying the hanging and 

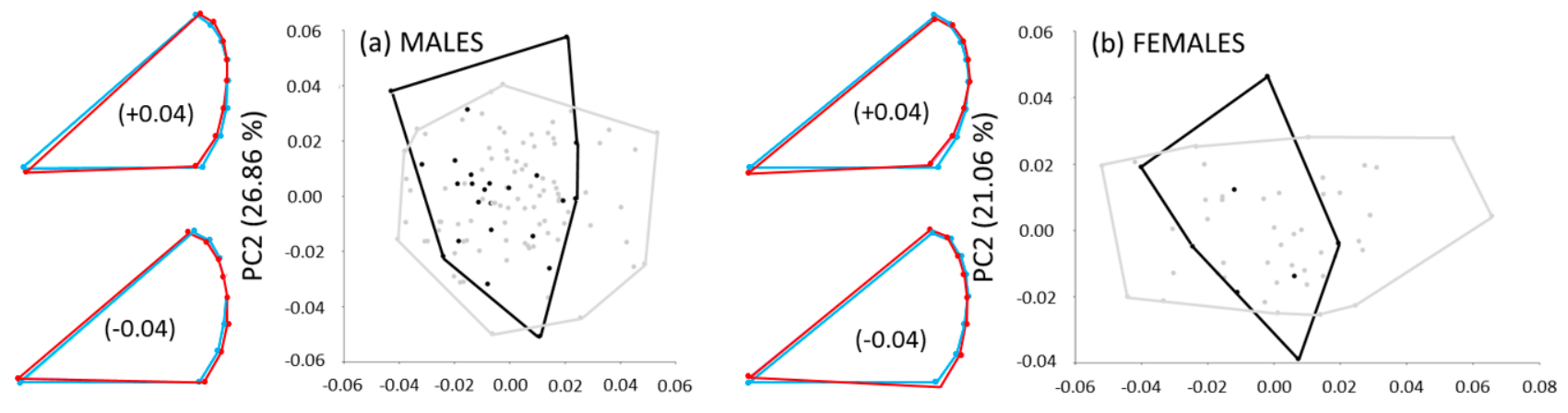

\section{Forewing}
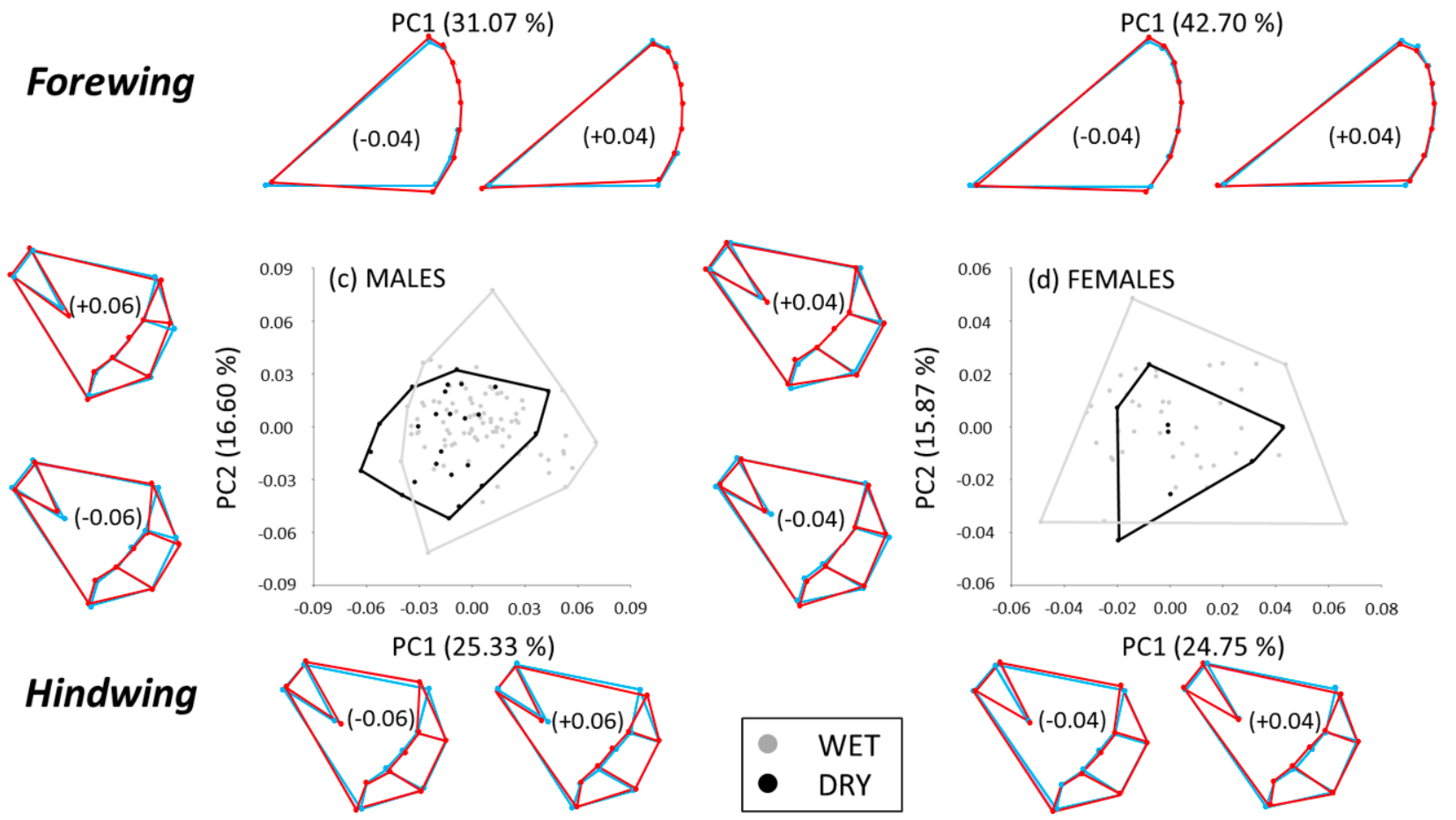

Hindwing
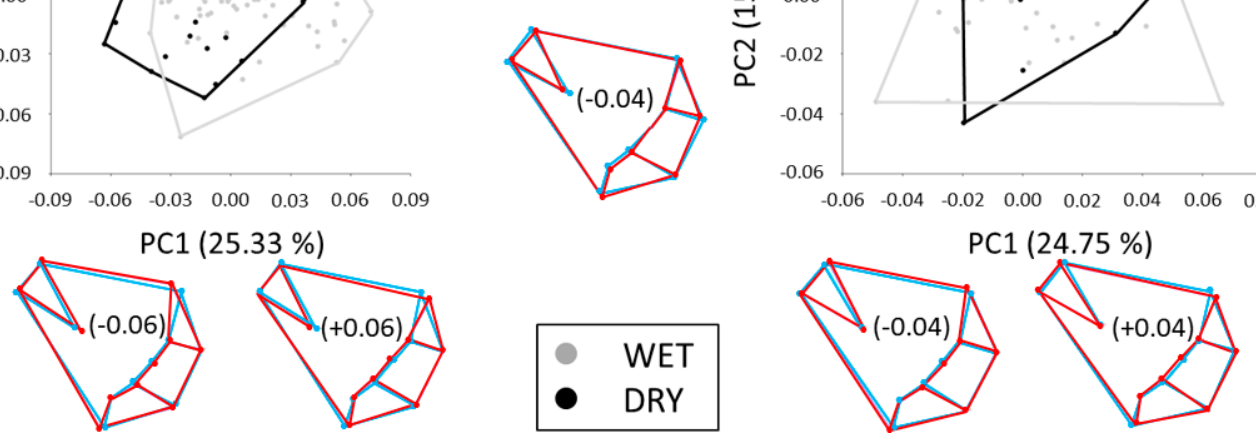

Fig. 3. Principal component analysis of ecotype dimorphism in wing shape parameters obtained using geometric morphometry of $C$. oedippus specimens from wet and dry habitats: (a) males-forewing, (b) females-forewing, (c) males-hindwing, (d) females-hindwing. Deviations from centroid shape (blue) are denoted by red wireframe graphs along PC axes at given values (in brackets within each wireframe). Percentage of explained variance is added in brackets for each PC axis.

motionless male when copula is disturbed (Čelik, pers. observ.). The sex of the flying partner is also species-specific and appears to be a phylogenetically conservative trait (Wiklund, 2003).

Female-biased sexual dimorphism in wing size was more pronounced in the wet than in the dry ecotype. Magnitude of sexual dimorphism is known to vary across the range of this species (Connallon, 2015) and is explained in terms of sex-specific plasticity for body size, where environmental variability (especially in diet quality and developmental temperature) triggers different responses in males and females (Stillwell et al., 2010). There is no significant sex difference in the average degree of plasticity for wing size within each ecotype, yet sexual dimorphism in wing size is more pronounced in the wet ecotype. This may be explained by different counteractions between sources of sexual and fecundity selection operating in wet compared to dry habitats. Hence, the intensity of selection might differ in the two habitats due to differences in resource availability and population dynamics. Namely, the population density of $C$. oedippus is greater in wet than in dry habitats in Slovenia (cf. Čelik, 2003, 2015; Čelik et al., 2009; Verovnik et al., 2015; Rakar, 2016). Population density affects mate finding dynamics and intensity of sexual selection. In both habitats, selection for an increase in fecundity may have resulted in large females and sexual selection in small males. However, the greater availability of resources and increased population density in the wet habitat allow females to reach a larger size and selects for smaller males, respectively. In the dry habitat, the low availability of resources may affect female size in different directions. Wing size in females may result from a trade-off between two life-history traits, i.e. fecundity and choice of oviposition sites (Jaumann \& Snell-Rodds, 2017). Namely, females of C. oedippus are selective in terms of the vegetation structure and microclimate at their oviposition sites (Čelik et al., 2015). Eggs are more likely to desiccate in the dry habitats where there is a lower availability of host-plants than in wet habitats. Therefore, females have to invest more time and energy finding suitable microhabitats and thus reducing the possibility of their offspring desiccating. This choosiness implies a higher level of mobility and thus smaller wings 
Table 5. Generalised linear models for testing the effect of environmental parameters (T-temperature, $\mathrm{P}$-precipitation, $\mathrm{H}$-air humidity, HPs-abundance of larval hostplants), sex (female $=0$, male $=1$ ) and interactions between sex and environmental factors on forewing and hindwing length (FWL2, HWL4), width (FWH, HWL3) and hindwing ocellation (sums hws) of C. oedippus from wet and dry habitats. HPs was treated as a factor (using median value for wet and dry habitats, respectively) and consequently also as a predictor for ecotype. Only models with $\triangle \mathrm{AICc}<2$ are shown.

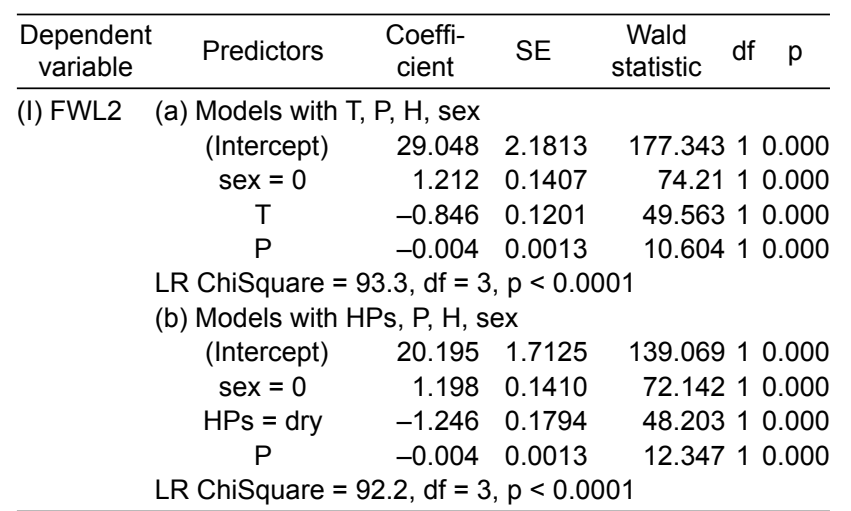

\begin{tabular}{|c|c|c|c|c|}
\hline \multirow[t]{16}{*}{ (II) $\mathrm{FWH}$} & \multicolumn{4}{|c|}{ (a) Models with $T, P, H$, sex } \\
\hline & (Intercept) & 17.181 & 1.6133 & 113.4110 .000 \\
\hline & $\operatorname{sex}=0$ & 0.136 & 0.1659 & 0.66810 .414 \\
\hline & $\mathrm{T}$ & -0.428 & 0.1438 & 8.83810 .003 \\
\hline & \multicolumn{4}{|c|}{ LR ChiSquare $=9.0, \mathrm{df}=2, \mathrm{p}<0.05$} \\
\hline & (Intercept) & 17.137 & 1.6152 & 112.56910 .000 \\
\hline & $\mathrm{T}$ & -0.421 & 0.1438 & 8.54910 .000 \\
\hline & \multirow{2}{*}{\multicolumn{4}{|c|}{$\begin{array}{l}\text { LR ChiSquare }=8.4 \text {, df }=1, p<0.01 \\
\text { (b) Models with HPs, P, H, sex }\end{array}$}} \\
\hline & & & & \\
\hline & (Intercept) & 12.474 & 0.0892 & 19535.410 .000 \\
\hline & $\operatorname{sex}=0$ & 0.125 & 0.1655 & 0.57310 .449 \\
\hline & HPs = dry & -0.649 & 0.2138 & 9.20310 .002 \\
\hline & \multicolumn{4}{|c|}{ LR ChiSquare $=9.4, \mathrm{df}=2, \mathrm{p}<0.01$} \\
\hline & (Intercept) & 12.506 & 0.0785 & 5364.14210 .000 \\
\hline & HPs = dry & -0.642 & 0.2139 & 9.01210 .003 \\
\hline & \multicolumn{4}{|c|}{ LR ChiSquare $=8.8, \mathrm{df}=1, \mathrm{p}<0.01$} \\
\hline
\end{tabular}

(III) HWL4 (a) Models with T, P, H, sex $\begin{array}{crr}\text { (Intercept) } & 18.483 & 1.6477 \\ \text { sex }=0 & 5.752 & 2.8254 \\ T & -0.297 & 0.1470\end{array}$ sex $=0 * T \quad-0.404 \quad 0.2510$

LR ChiSquare $=74.2, \mathrm{df}=3, \mathrm{p}<0.0001$ $\begin{array}{llllll}\text { (Intercept) } \quad 20.033 & 1.3451 & 221.826 & 1 & 0.000\end{array}$ $\begin{array}{llllll}\text { sex }=0 & 1.214 & 0.1383 & 77.073 & 1 & 0.000\end{array}$

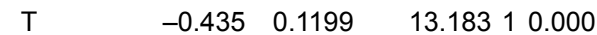

LR ChiSquare $=71.6, \mathrm{df}=2, \mathrm{p}<0.0001$

(b) Models with HPs, $\mathrm{P}, \mathrm{H}$, sex

$\begin{array}{llllll}\text { (Intercept) } \quad 15.209 & 0.075540603 .027 & 1 & 0.000\end{array}$

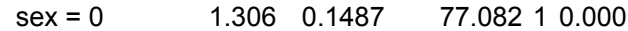
HPs = dry $\quad-0.415 \quad 0.212 \quad 3.82610 .050$ sex $=0 \mathrm{HPs}=$ dry $\quad-0.699 \quad 0.3869 \quad 3.26610 .071$

LR ChiSquare $=73.9, \mathrm{df}=3, \mathrm{p}<0.0001$

(Intercept) $\quad 15.236 \quad 0.074741652 .53410 .000$ $\begin{array}{llllll}\text { sex }=0 & 1.203 & 0.1385 & 75.425 & 10.000\end{array}$ HPs $=$ dry $\quad-0.625 \quad 0.1788 \quad 12.210 .000$

LR ChiSquare $=70.7, \mathrm{df}=2, \mathrm{p}<0.0001$

(IV) HWL3 (a) Models with T, P, H, sex $\begin{array}{crrrrr}\text { (Intercept) } & 16.781 & 0.8681 & 373.652 & 1 & 0.000 \\ \text { sex }=0 & 0.366 & 0.0893 & 16.804 & 1 & 0.000 \\ T & -0.393 & 0.0774 & 25.812 & 1 & 0.000\end{array}$

LR ChiSquare $=36.6, \mathrm{df}=2, \mathrm{p}<0.0001$

(b) Models with HPs, $\mathrm{P}, \mathrm{H}$, sex

$\begin{array}{lllll}\text { (Intercept) } \quad 12.449 & 0.048765249 .20410 .000\end{array}$ $\begin{array}{llllll}\text { sex }=0 & 0.374 & 0.0960 & 15.129 & 1 & 0.000\end{array}$ HPs = dry $\quad-0.572 \quad 0.1369 \quad 17.48610 .000$ sex $=0$ *HPs $=$ dry $\quad-0.113 \quad 0.2498 \quad 0.20610 .650$ LR ChiSquare $=38.7, \mathrm{df}=3, \mathrm{p}<0.0001$
Table 5 (continued).

\begin{tabular}{|c|c|c|c|c|c|}
\hline $\begin{array}{l}\text { Dependent } \\
\text { variable }\end{array}$ & Predictors & $\begin{array}{l}\text { Coeffi- } \\
\text { cient }\end{array}$ & SE & $\begin{array}{l}\text { Wald } \\
\text { statistic }\end{array}$ & df \\
\hline & (Intercept) & 12.454 & 0.0478 & 67805.609 & 10.000 \\
\hline & $\operatorname{sex}=0$ & 0.357 & 0.0887 & 16.177 & 10.000 \\
\hline & $\mathrm{HPs}=$ dry & -0.606 & 0.1146 & 28.023 & 10.000 \\
\hline \multicolumn{6}{|c|}{ LR ChiSquare $=38.5, \mathrm{df}=2, \mathrm{p}<0.0001$} \\
\hline \multicolumn{6}{|c|}{ (V) sums_hws (a) Models with $T, P, H$, sex } \\
\hline & (Intercept) & -0.046 & 0.0531 & 0.749 & 10.387 \\
\hline & $\operatorname{sex}=0$ & 0.209 & 0.0910 & 5.290 & 10.021 \\
\hline & $\mathrm{T}$ & 0.016 & 0.0047 & 11.072 & 10.001 \\
\hline & $\operatorname{sex}=0 * T$ & -0.017 & 0.0081 & 4.649 & 10.031 \\
\hline \multicolumn{6}{|c|}{$\begin{array}{l}\text { LR ChiSquare }=20.1, \mathrm{df}=3, \mathrm{p}<0.0001 \\
\text { (b) Models with HPs, P, H, sex }\end{array}$} \\
\hline & (Intercept) & 0.128 & 0.0024 & 2747.743 & 10.000 \\
\hline & $\operatorname{sex}=0$ & 0.017 & 0.0048 & 12.694 & 10.000 \\
\hline & HPs = dry & 0.021 & 0.0068 & 9.653 & 10.002 \\
\hline & $x=0 * H P s=d r y$ & -0.024 & 0.0125 & 3.670 & 10.055 \\
\hline \multicolumn{6}{|c|}{ LR ChiSquare $=18.8, \mathrm{df}=3, \mathrm{p}<0.0001$} \\
\hline
\end{tabular}

in females from dry habitats. Consequently, this should be reflected in a smaller wing-size difference between sexes in the dry than in the wet ecotype. Similarly, Gibbs et al. (2012) also reports that the quality of host-plants is an environmental factor responsible for the difference in the sexual size dimorphism in populations of satyrid butterflies in different types of landscape. They report that larval development on drought-stressed hostplants had sex-specific effects on adult body mass and wing loading, with both being more reduced in females than in males.

Ecotype dimorphism in wing size (EDI) did not differ between sexes neither in direction (wet $>$ dry) or in degree. Females have a higher EDI than males but the difference is not significant. Ecotype dimorphism in wing size of $C$. oedippus is best explained by mean annual air temperature and abundance of host-plants operating in opposite directions, i.e. individuals with large wings originate from habitats with a lower temperature and higher abundance of host-plants (wet habitats). Such ecotype-based wing size dimorphism in C. oedippus conforms to the temperaturesize rule (TSR), i.e. development at high temperatures result in small adult sizes in ectotherms (Kingsolver \& Huey, 2008), and to the generalization that ectotherms raised on lower-quality diets mature at a smaller size (Stilwell et al., 2010; Hirst et al., 2015).

Wet-biased ecotype dimorphism in wing size could be due to the behavioural and physiological mechanisms that result in larger body sizes at low temperatures recorded in other herbivorous insects. The behavioural mechanism includes decreased consumption rate of larvae at high temperature due to metabolic demands exceeding energetic supply (Somero, 2011). In addition, it is likely that the time and energy spent by larvae searching for a new host in dry than in wet ecotypes differ because of the lower cover of host-plants in dry habitats. The physiological mechanism involves a decreased growth efficiency (i.e. conversion of ingested food into body matter) at high temperatures (Karl $\&$ Fischer, 2008). However, as the nutritional quality of host-plants is known to generate intraspecific differences in the shape of the thermal response curve of consumption 
rate (Lemoine et al., 2014), this might also be the reason for wet-biased ecotype dimorphism in the wing size of $C$. oedippus. Host-plant nutritional value (leaf nitrogen, carbon and water content) decrease with drought stress (Talloen et al., 2004), which is more likely in warm and sunny dry habitats. As the soils in dry habitats (i.e. limestone, dolomite, flysch) are more permeable than in wet habitats (i.e. peat and other types of hydromorphic soil) their water content is likely to be lower, which increases the probability of the larval host-plants desiccating. Different effects of drought stress are reported for temperate (Pararge aegeria) and tropical (Bicyclus anynana) butterflies; e.g. despite the prolonged larval developments in both species due to low host-plant quality, adults subjected to drought stress have smaller wings than control individuals in P. aegeria (Talloen et al., 2009) and larger wings in B. anynana (Kooi et al., 1996). Thus, since the larval development time of $C$. oedippus in the warmer climatic conditions in the dry habitats is longer than in the wet habitats but resulted in smaller wings, we suppose that the main environmental factors that induce phenotypic differences in wing size between ecotypes of $C$. oedippus are the availability and nutritional quality of the host-plants.

\section{Wing ocellation}

Females have more eyespots on their forewings than males. That this difference is only associated with sex (not habitat) indicates that the number of eyespots has a sex-related function. Females are the more sedentary sex, whereas males are more mobile and use patrolling as a mate-location strategy (Čelik, 2003; Čelik et al., 2009). A high number of eyespots on the ventral surface of the wings of females may have an antipredator function. The eyespots are best visible and more conspicuous at rest, and therefore may be particularly advantageous in females. According to the deflection hypothesis (Blest, 1957), females more efficiently draw the attention of a predator towards their marginal band of eyespots and consequently deflect the attack of a predator away from vital body parts. Butterflies may have eyespots on both wing surfaces (dorsal, ventral), dorsal wing patterns are important in mating, while those on the ventral surface are more subject to selection by natural enemies and thus appear to play an important role in predator avoidance (Oliver et al., 2009). While the dorsal wing surface in $C$. oedippus is uniform dark brown with no obvious ocelli, males and females significantly differ in number of eyespots on the ventral surface of their forewings. This indicates that these eyespots may play a role in mate signalling as butterflies can expose or hide the forewing behind the hindwing when resting.

Sexual dimorphism in the size of hindwing eyespots $\left(\mathrm{SDI}_{1}\right)$ is female-biased in both ecotypes and more expressed in the wet than in the dry ecotype. The direction of sexual dimorphism in relative area of eyespots on the hindwing $\left(\mathrm{SDI}_{2}\right)$ differs between ecotypes, being femalebiased in the wet, but male-biased in the dry ecotype. The $\mathrm{SDI}_{2}$ is also higher in the wet than in the dry ecotype. Together with the increased number of eyespots on the forewings, the female-biased $\mathrm{SDI}_{1}$ and $\mathrm{SDI}_{2}$ in wet habi- tats might serve as a deflecting mechanism reducing the incidence of predator attacks on resting females. Ecotype dimorphism for the absolute (EDI $)_{1}$ ) and relative size of the eyespots on the hindwing $\left(\mathrm{EDI}_{2}\right)$ differs between sexes in both direction and magnitude. EDI ${ }_{1}$ and $\mathrm{EDI}_{2}$ are dry habitat-biased in males but wet habitat-biased in females. While EDI ${ }_{1}$ is significantly more pronounced in females, $\mathrm{EDI}_{2}$ is more expressed in males. Such sex and habitatspecific conspicuousness of the eyespots on the hindwing indicates that different selection pressures on eyespot size operate in each of the ecotypes. One possible explanation of this is the difference in climatic conditions in the two habitats as is indicated by the significant interaction between sex and temperature in the best model. In the dry habitats, the butterflies are likely to be more active as it is sunnier and warmer there. Increased activity renders a butterfly more visible to predators. Thus, in dry habitats predation pressure is greatest when the butterflies are flying or changing behaviour as they are then more evident to predators but still warm enough to evade predator attacks. In the colder wet habitats, butterflies are probably more exposed to predators when at rest as this behavioural activity is presumably more frequent in the colder than in the warmer ecotype due to the longer time needed to warm up enough for flying. Hence, the intensity of selection mechanisms for avoiding predators, i.e. conspicuous eyespots on hindwing, may differ in these two habitats and sexes depending on which sex is more exposed in a given environment. Namely, selection for more conspicuous eyespots might be more intense in the more mobile sex in warmer habitats (i.e. male) but in the less mobile sex in colder climatic conditions (i.e. female). Assuming the females in the wet habitat are more fecund than in the dry habitat due to a trade-off between fecundity and choosiness in dry habitats (see above: Wing size), it is very likely that females in wet habitats have a higher wing loading and hence have to rest more. The size of the eyespots on the hindwing may also be affected by host-plant quality. For example, poor food quality prolongs the length of larval development and decreases spot size in the tropical butterfly B. anynana (Kooi et al., 1996). Together with air temperature, the abundance of host-plants is also one of the key environmental factors affecting the relative size of the of eyespots on the hindwing in $C$. oedippus. Accordingly, the expectation is that the eyespots in the dry ecotype will be smaller. While this corroborates our findings in females, males from dry habitats have relatively larger eyespots than those in wet habitats. As the absolute size of each individual eyespot on the hindwing $\left(\mathrm{EDI}_{1}\right)$ of males in the dry habitats exceeds that of males in the wet habitats the larger relative area of eyespots in dry than in wet habitat in males $\left(\mathrm{EDI}_{2}\right)$ is not simply the result of an ecotype difference in hindwing size (EDI: dry < wet). In females, the size of each eyespot on the hindwing has the opposite pattern (EDI. wet $>$ dry) to that in males but the ecotype difference in hindwing size (EDI) has the same direction as in males, resulting in nonsignificant differences in the relative area of eyespots in both types of females (Table 2). This difference in the pat- 
tern of ecotype dimorphism in the relative area of eyespots in the sexes is in accordance with the assumption of Brakefield et al. (1996) that butterfly eyespot patterns (including size) can evolve independently of other wing-pattern elements and body structures.

However, in C. oedippus the average degree of plasticity for traits associated with wing ocellation $\left(\mathrm{CVm}_{1}, \mathrm{CVm}_{2}\right)$ is two to three times higher than for those correlated with wing size $(\mathrm{CVm})$. Considering predictions of the adaptive canalization hypothesis and condition dependence hypothesis (Stilwell et al., 2010), we presume that wing size is a more canalized trait than is the size of hindwing eyespots in $C$. oedippus and a deviation from the average wing-size phenotype might have larger negative fitness consequences than phenotypic variation in the conspicuousness of hindwing eyespots. The direction of sexual wing-size dimorphism being the same in both ecotypes (females $>$ males) together with the opposite direction for both sexual and ecotype dimorphism in the conspicuousness of hindwing eyespots (wet habitat: females $>$ males; dry habitat: males $>$ females; males: dry $>$ wet; females: wet $>$ dry) indicates that wing-size traits are under strong stabilizing selection while hindwing eyespots, which are more sensitive to environmental conditions, are subject to directional selection.

\section{Wing shape}

Sexual dimorphism in wing shape occurs in both habitats, while differences in wing shape between ecotypes occurs only in males, and even then only in that of the hindwings. It is widely accepted that the sexual wing shape dimorphism common to most butterflies originates from differences in the flight behaviour of the sexes (Berwaerts et al., 2006). For many species of butterfly wing-shape is associated with habitat (DeVries et al., 2010; but see Breuker et al., 2010), habitat fragmentation (Merckx \& Van Dyck, 2006; Breuker et al., 2007; Bai et al., 2015) or even larval diet (Berns, 2014). As the ecotypes of $C$. oedippus studied differ in all of the three environmental factors mentioned above and wing shape in butterflies evolved to improve aerodynamic efficiency (Dudley, 1990), wing shape plasticity is to be expected in this species. Sexual wing shape dimorphism in C. oedippus is probably related to mate location behaviour with males spending more time flying than females. Longer and slenderer wings in females and shorter and broader wings in males of both ecotypes indicate that short and broad wings may be more advantageous for the more mobile sex (i.e. the prolonged flights of patrolling males) as shorter and broader wings (i.e. lower wing aspect ratio) enable high efficiency in long-distance flights (Hassall, 2015) and consequently increase the probability of escaping a predator attack during flight, or increase their success in searching for mates. This assumption is supported by the difference in hindwing shape of the males from different habitats. Namely, the dry habitat ecotype, which lives in a warmer habitat allowing greater daily activity, has more rounded hindwings than the wet habitat ecotype, which lives in colder conditions. However, the differences in the shape of only the hind wings of males indicate that wing shape is probably not constrained by habitat. It is also possible that differences in the wing shape of females in the two habitats were not detected due to small sample sizes. Assuming that wing shape in butterflies is related mostly to their migration and dispersal abilities (Breuker et al., 2007; Dockx, 2007), the very low dispersal ability of both sexes of C. oedippus (Čelik, 2003; Bonelli et al., 2010; Örvössy et al., 2010; Šašić, 2010) could be a possible reason for the high stability in ecotype-related wing shape. Clearly expressed differences between ecotypes in wing size (wet $>$ dry) but not in wing shape indicate that wing morphology is probably more associated with other environmental factors, such as availability and quality of host-plants. Similar patterns in the plasticity of wing morphology is reported in the butterfly $P$. aegeria, in which there is seasonal plasticity in wing size and colour (Van Dyck \& Wiklund, 2002), but landscape-related phenotypic plasticity is detected only for thorax mass and wing-loading (Merckx \& Van Dyck, 2006) and not for wing shape (Breuker et al., 2010). It seems that wing shape in C. oedippus is more conserved but further studies are needed to establish the exact role of genetic and environmental variation on this wing trait, especially with regard to the finding (Outomuro et al., 2016) that wing shape in insects could be under antagonistic natural and sexual selection.

We show that morphological traits of $C$. oedippus, such as wing size, shape and ocellation, differ significantly within this species, which indicates this species can adapt to a range of environmental conditions. Wing traits vary depending on environmental factors related to habitat (wing size, relative area of eyespots on hindwings), and sex (wing size and shape). Early results of the pattern of genetic diversity within all Slovenian populations of $C$. oedippus, revealed by mitochondrial DNA markers, indicate no clear connection between genetic variability (haplotype diversity) and habitat (Zupan et al., 2016, Zupan et al., in prep.). A multigene analysis is needed to clarify the genetic pattern of population adaptation and determine which genes/regions are responsible for ecotype differences in wing size and ocellation of populations at the southern edge of this species' range.

ACKNOWLEDGEMENTS. Special thanks to two anonymous referees for suggestions that greatly improved the manuscript, and to S. Kralj-Fišer for the English revision of the text. We are grateful to T. Trilar, T. Koren, I. Jugovic, M. Sukič, B. Vreš, K. Kalan, B. Surina, E. Praprotnik, T. Zagoršek, A. Popovič, V. Šugar, A. Franca, B. Gaberšek, N. Fujs, D. Domazet, M. Jančič, N. Koprivnikar, M. Cerar, M. Kučić, M. Črne, K.P. Jarc, P. Sovdat, D. Trkov, I. P. Strozak, A.M. Pavlin, M. Kolenc and L. Rušnjak for help during field work and data preparation. TC was supported by the Slovenian Research Agency (grant P1-0236); JJ was supported by a post-doctoral project at University of Primorska (grant UP1142-59/2012).

\section{REFERENCES}

Abramoff M.D., Magalhaes P.J. \& Ram S.J. 2004: Image processing with ImageJ. - Biophotonics Intern. 11: 36-42.

Adams D.C., Rohlf. F.J. \& Slice D.E. 2004: Geometric morphometrics: Ten years of progress following the revolution. - Ital. J. Zool. 71: 5-16. 
BAI Y., MA L.B., XU S.Q. \& WANG G.H. 2015: A geometric morphometric study of the wing shapes of Pieris rapae (Lepidoptera: Pieridae) from the Qinling Mountains and adjacent regions: An environmental and distance-based consideration. - Fla Entomol. 98: 162-169.

Berwaerts K., Aerts P. \& Van Dyck H. 2006: On the sex-specific mechanisms of butterfly flight: flight performance relative to flight morphology, wing kinematics, and sex in Pararge aegeria. - Biol. J. Linn. Soc. 89: 675-687.

Bischof A. 1968: Coenonympha oedippus Fabricius, eine kleine Chorographie (Lepidoptera, Satyridae). - Mitt. Entomol. Ges. Basel 18: 41-63.

BLEst A.D. 1957: The function of eyespot patterns in the Lepidoptera. - Behavior 11: 209-255.

Bonelli S., Canterino S. \& Balletto E. 2010: Ecology of Coenonympha oedippus (Fabricius, 1787) (Lepidoptera: Nymphalidae) in Italy. - Oedippus 26: 25-30.

BooKstein F.L. 1989: Principal warps, thin-plane splines and the decomposition of deformations. - IEEE Trans. Pattern Anal. Mach. Intell. 11: 567-585.

Bowden J.J., Eskildsen A., Hansen R.R., Olsen K., Curle C.M. \& Høyе T.T. 2015: High-arctic butterflies become smaller with rising temperatures. - Biol. Lett. 11: 1-4.

Bozano G.C. 2002: Guide to the Butterflies of the Palearctic Region. Satyrinae, Part III. Omnes Artes, Milan, 71 pp.

Brakefield P.M., Gates J., Keys D., Kesbeke F., Wijngaarden P.J., Monteiro A., French V. \& Carroll S.B. 1996: Development, plasticity and evolution of butterfly eyespot patterns. Nature 384: 236-242.

BReUKer C.J., BRAKEFIELD P.M. \& GibBS M. 2007: The association between wing morphology and dispersal is sex-specific in the glanville fritillary butterfly Melitea cinxia (Lepidoptera: Nymphalidae). — Eur. J. Entomol. 104: 445-452.

Breuker C.J., Gibbs M., Van Dongen S., Merckx T. \& Van Dyck H. 2010: The use of geometric morphometrics in studying butterfly wings in an evolutionary ecological context. In Elewa A.M.T. (ed.): Morphometrics for Nonmorphometricians. Springer, Berlin, pp. 271-287.

Burnham K.P. \& ANDERson D. 2002: Model Selection and MultiModel Inference. A Pratical Information - Theoretic Approach. Springer, New York, 488 pp.

Connallon T. 2015: The geography of sex-specific selection, local adaptation, and sexual dimorphism. - Evolution 69: 2333-2344.

ČElIK T. 2003: Population Structure, Migration and Conservation of Coenonympha oedippus Fabricius, 1787 (Lepidoptera: Satyridae) in a Fragmented Landscape. PhD Thesis, University of Ljubljana, xvii + $100 \mathrm{pp}$

ČELIK T. 2015: Monitoring of Target Species: False Ringlet (Coenonympha oedippus). People for Marsh - Biodiversity Conservation at the Ljubljana Marsh. Final Report. Institute of Biology Jovan Hadži ZRC SAZU, Ljubljana, 31 pp. [in Slovenian].

ČELIK T. \& Verovnik R. 2010: Distribution, habitat preferences and population ecology of the False Ringlet Coenonympha oedippus (Fabricius, 1787) (Lepidoptera: Nymphalidae) in Slovenia. - Oedippus 26: 7-15.

ČeliK T., VReš B. \& SelišKar A. 2009: Determinants of withinpatch microdistribution and movements of endangered butterfly Coenonympha oedippus (Fabricius, 1787) (Nymphalidae: Satyrinae). - Hacquetia 8: 115-128.

Č́lit T., Bräu M., Bonelli S., Cerrato C., Vreš B., Balletto E., StetTMer C. \& Dolek M. 2015: Winter-green host-plants, litter quantity and vegetation structure are key determinants of habitat quality for Coenonympha oedippus in Europe. - J. Insect Conserv. 19: 359-375.
DAVIES W.J. \& SACCHERI I.J. 2017: Evolution of adaptive phenotypic plasticity in male orange-tip butterflies. - Ann. Zool. Fenn. 54: 225-236.

De Jong M.A., Kesbeke F.M.N.H., Brakefield P.M. \& Zwan B.J. 2010: Geographic variation in thermal plasticity of life history and wing pattern in Bicyclus anynana. - Clim. Res. 43: $91-102$.

Dennis R.L.H., Porter K. \& Williams W.R. 1986: Ocellation in Coenonympha tullia (Müller) (Lepidoptera: Satyridae). II. Population differentiation and clinal variation in the context of climatically induced antipredator defence strategy. - Entomol. Gaz. 37: 133-172.

DeVries P.J., Penz C.M. \& Hill R.I. 2010: Vertical distribution, flight behaviour and evolution of wing morphology in Morpho butterflies. - J. Anim. Ecol. 79: 1077-1085.

Dockx C. 2007: Directional and stabilizing selection on wing size and shape in migrant and resident monarch butterflies, Danaus plexippus (L.), in Cuba. - Biol. J. Linn. Soc. 92: 605-616.

FAGESTRÖM T. \& WiKLUND C. 1982: Why do males emerge before females? Protandry as a mating strategy in male and female butterflies. - Oecologia 52: 164-166.

FAIRBAIRN D.J. 1997: Allometry for sexual size dimorphism: Pattern and process in the coevolution of body size in males and females. - Annu. Rev. Ecol. Evol. Syst. 28: 659-687.

Fischer K. \& Fiedler K. 2001: Dimorphic growth patterns and sex-specific reaction norms in the butterfly Lycaena hippothoe sumadiensis. - J. Evol. Biol. 14: 210-218.

Ghalambor C.K., McKay J.K., Carroll S.P. \& Reznick D.N. 2007: Adaptive versus non-adaptive phenotypic plasticity and the potential for contemporary adaptation in new environments. - Funct. Ecol. 21: 394-407.

GibBS M., WiKLUnd C. \& VAN DycK H. 2011: Temperature, rainfall and butterfly morphology: Does life history theory match the observed pattern? - Ecography 34: 336-344.

Gibis M., Van Dyck H. \& BreuKer C.J. 2012: Development on drought-stressed host plants affects life history, flight morphology and reproductive output relative to landscape structure. Evol. Appl. 5: 66-75.

Hassall C. 2015: Strong geographical variation in wing aspect ratio of a damselfly, Calopteryx maculata (Odonata: Zygoptera). - PeerJ 3: e1219, 17 pp.

Higgins L.G. \& RiLey N.D. 1993: A Field Guide to the Butterflies of Britain and Europe. 5th ed. Harper Collins, London, 384 pp.

HiRst A.G., Horne C.R. \& AtKinson D. 2015: Equal temperature - size responses of the sexes are widespread within arthropos species. - Proc. R. Soc. (B) 282: 20152475, 9 pp.

Ho S., Schachat S.R., Piel W.H. \& Monteiro A. 2016: Attack risk for butterflies changes with eyespot number and size. $-R$. Soc. Open Sci. 3: 150614, 13 pp.

Jaumann S. \& Snell-Roods E.C. 2017: Trade-offs between fecundity and choosiness in ovipositing butterflies. - Anim. Behav. 123: 433-440.

Joyce D.A., Dennis R.L.H. \& Bryant S.R., Shreeve T.G., Ready J.S \& PULLIN A.S. 2009: Do taxonomic divisions reflect genetic differentiation? A comparison of morphological and genetic data in Coenonympha tullia (Müller), Satyrinae. - Biol. J. Linn. Soc. 97: 314-327.

KARL I. \& Fischer K. 2008: Why get big in cold? Towards a solution to a life-history puzzle. - Oecologia 155: 215-225.

Kingsolver J.G. \& Huey R.B. 2008: Size, temperature, and fitness: three rules. - Evol. Ecol. Res. 10: 251-268.

Kingsolver J.G., Izem R. \& Ragland G.J. 2004: Plasticity of size and growth in fluctuating thermal environments: comparing reaction norms and performance curves. - Integr. Сomp. Biol. 44: 450-460. 
Kooi R.E., Brakefield P.M. \& Rossie W.E.M. 1996: Effects of food plant on phenotypic plasticity in tropical butterfly Bicyclus anynana. - Entomol. Exp. Appl. 80: 149-151.

KučInIČ M., TVrtKović N. \& KleteČKI E. 1999: The false fringlet (Coenonympha oedippus $\mathrm{F}$.) is a member of the Croatian fauna after all. - Nat. Croat. 8: 399-405.

Lemoine N.P., Burkepile D.E. \& PARKer J.D. 2014: Variable effects of temeperature on insect herbivory. - PeerJ 2: e376, $18 \mathrm{pp}$.

Lovich J.E. \& GibBons J.W. 1992: A review of techniques for quantifying sexual size dimorphism. — Growth Dev. Aging 56: 269-281.

MerckX T. \& VAn Dyck H. 2006: Landscape structure and phenotypic plasticity in flight morphology in the butterfly Pararge aegeria. - Oikos 113: 226-232.

Nosil P. 2012: Ecological Speciation. Oxford Series in Ecology and Evolution. Oxford University Press, Oxford, $280 \mathrm{pp}$.

NYLIN S. 2009: Gradients in butterfly biology. In Settele J., Shreeve T., Konvička M. \& Van Dyck H. (eds): Ecology of Butterflies in Europe. Cambridge University Press, Cambridge, pp. 199-216.

Oliver J.C., Robertson K.A \& Monteiro A. 2009: Accommodating natural and sexual selection in butterfly wing pattern evolution. - Proc. R. Soc. Lond. (B) 276: 2369-2375.

Olofsson M., Vallin A., Jakobsson S. \& WikLund C. 2010: Marginal eyespots on butterfly wings deflect bird attacks under low light intensities with UV wavelengths. - PLOS ONE 5: e10798, 6 pp.

Örvössy N., VozÁr Á., KörösI Á. \& Peregovitz L. 2010: Structure and size of a threatened population of the False Ringelt Coenonympha oedippus (Fabricius, 1787) (Lepidoptera: Nymphalidae) in Hungary. - Oedippus 26: 31-37.

Outomuro D., Söderquist L., Nilsson-Örtman V., CortázarChinarro M., Lundgren C. \& Johansson F. 2016: Antagonistic natural and sexual selection on wing shape in a scrambling damselfly. - Evolution 70: 1582-1595.

Pigliucci M., Murren C.J. \& Schlichting C.D. 2006: Phenotypic plasticity and evolution by genetic assimilation. - J. Exp. Biol. 209: 2362-2367.

Pincheira-Donoso D. \& Hunt J. 2017: Fecundity selection theory: concepts and evidence. - Biol. Rev. 92: 341-356.

RaKar B. 2016: Population Structure and Conservation of the False Ringlet (Coenonympha oedippus) in the Dragonja Valley. Master thesis, University of Ljubljana, xiv $+92 \mathrm{pp}$. [in Slovenian].

Robertson K.A. \& Monteiro A. 2005: Female Bicyclus anynana butterflies choose males on the basis of their dorsal UV-reflective eyespot pupils. - Proc. R. Soc. Lond. (B) 272: 1541-1546.

RoHLF F.J. 2006: TpsDig2.10. Department of Ecology and Evolution, State University of New York, Stony Brook.

RoHLF F.J. \& SLICE D. 1990: Extensions of the procrustes method for the optimal superimposition of landmarks. - Syst. Zool. 39: $40-59$.

SHEETS H.D. 2002: Morphometrics Software: IMP6-Integrated Morphometrics Package. URL: https://www3.canisus. edu/ $/$ sheets/morphsoft.html

SHINE R. 1988: The evolution of large body size in females: a critique of Darwin's "fecundity advantage" model. - Am. Nat. 131: 124-131.

Shreeve T., KonvičKa M. \& VAN Dyck H. 2009: Functional significance of butterfly wing morphology variation. In Settele J., Shreeve T., Konvička M. \& Van Dyck H. (eds): Ecology of Butterflies in Europe. Cambridge University Press, Cambridge, pp. 171-188.
Somero G.N. 2011: Comparative physiology: a "crystal ball" for predicting consequences of global change. - Am. J. Physiol. Regul. Integr. Comp. Physiol. 301: R1-R14.

SRYGLEY R.B. \& Chai P. 1990: Flight morphology of Neotropical butterflies: palatability and distribution of mass to the thorax and abdomen. - Oecologia 84: 491-499.

Stillwell R.C., Blanckenhorn W.U., Teder T., Davidowitz G. \& Fox C.W. 2010: Sex differences in phenotypic plasticity affect variation in sexual size dimorphism in insects: from physiology to evolution. - Annu. Rev. Entomol. 55: 227-245.

ŠAšíc M. 2010: False Ringlet Coenonympha oedippus (Fabricius, 1787) (Lepidoptera: Nymphalidae) in Croatia: current status, population dynamics and conservation management. - Oedippus 26: 16-19.

Talloen W., Van Dyck H. \& Lens L. 2004: The cost of melanization: butterfly wing coloration under environmental stress. Evolution 58: 360-366.

Talloen W., Van Dongen S., Van Dyck H. \& Lens L. 2009: Environmental stress and quantitative genetic variation in butterfly wing characteristics. - Evol. Ecol. 23: 473-485.

Teder T. \& Tammaru T. 2005: Sexual size dimorphism within species increases with body size in insects. - Oikos 108: 321-334.

Tolman T. 2001: Photographic Guide to the Butterflies of Britain and Europe. Oxford University Press, $305 \mathrm{pp}$.

VAN DYCK H. \& WiKLUND C. 2002: Seasonal butterfly design: Morphological plasticity among three developmental pathways relative to sex, flight and thermoregulation. - J. Evol. Biol. 15: 216-225.

Van Swahy C., Cuttelod A., Collins S., Maes D., Munguira M.L., Šašlć M., Settele M., Verovinik R., Verstrael T., WaRREN M., Wiemers M. \& WyNhoff I. 2010: European Red List of Butterfies. Publ. of Eur. Union, Luxembourg, 47 pp.

Verovinik R., ZAKŠEK V., Govedič M., ZAKŠEK B., KogovŠEK N., Grobelnik V. \& Šalamun A. 2015: Monitoring of Selected Target Butterfly Species in 2014 and 2015: Final Report. University of Ljubljana, $154 \mathrm{pp}$. [in Slovenian].

WATT W.B. 2003: Mechanistic studies of butterfly adaptations. In Boggs C., Watt W. \& Ehrlich P. (eds): Butterflies: Ecology and Evolution Taking Flight. University of Chicago Press, Chicago, pp. 319-352.

WIKLUND C. 2003: Sexual selection and the evolution of butterfly mating systems. In Boggs C.L., Watt W.B. \& Ehrlich P.R. (eds): Ecology and Evolution Taking Flight. The University of Chicago Press, Chicago, pp. 67-90.

Zaninović K., Gajić-ČAPKa M., PerčEc Tadić M., Vučetić M., Milković J., Bají́ A., Cindrić K., Cvitan L., Katušin Z., Kaučić D., Likso T., LonČAR E., LonČar Ž., MihaJlović D., PAndžIĆ K., Patarčić M., SRnec L. \& VuČetić V. 2008: Climate atlas of Croatia 1961-1990, 1971-2000. Državni hidrometeorološki zavod, Zagreb, $200 \mathrm{pp}$.

Zupan S., Jugovic J., ČeliK T. \& BužAn E. 2016: An Insight into Genetic Population Structure of Butterfly False Ringlet, Coenonympha oedippus (Nymphalidae, Satyrinae) from Slovenia. In Future 4 Butterflies in Europe. Dutch Butterfly Conservation, Wageningen, $131 \mathrm{pp}$.

Received October 25, 2017; revised and accepted June 6, 2018 Published online July 17, 2018 


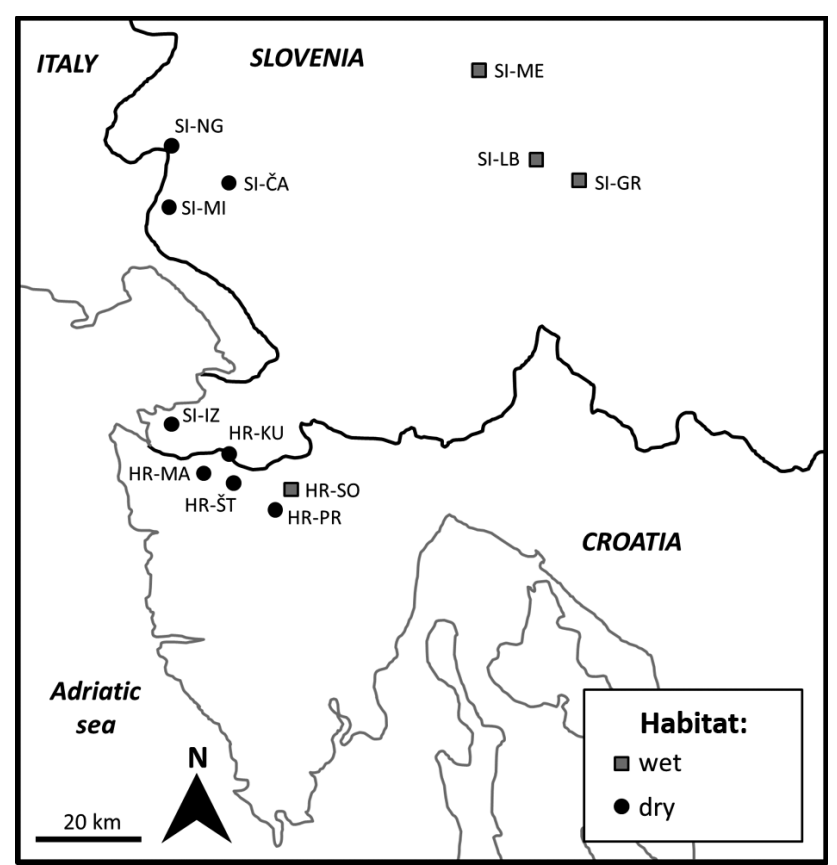

Appendix 1. Map showing the locations where the specimens used in the morphometric analyses of Coenonympha oedippus were collected.
Appendix 2. Locations, altitude, year and habitat in which the specimens were collected, and numbers of males $(M)$ and females $(F)$ included in the classical (CM) and geometric (GM) morphometric analysis of $C$. oedippus.

\begin{tabular}{|c|c|c|c|c|c|c|c|c|}
\hline $\begin{array}{l}\text { Location ID } \\
\text { (see App. 1) }\end{array}$ & $\begin{array}{l}\text { Location } \\
\text { name }\end{array}$ & $\begin{array}{l}\text { Altitude } \\
\text { (m) }\end{array}$ & $\begin{array}{l}\text { Collection } \\
\text { years }\end{array}$ & $\begin{array}{c}\text { Habitat } \\
\text { type }\end{array}$ & $\frac{\mathrm{Cl}}{\mathrm{M}}$ & $\mathrm{F}$ & $\frac{G N}{M}$ & \\
\hline SI-ME & Medno & 320 & 1977 & wet & 0 & 0 & & 0 \\
\hline SI-LB & $\begin{array}{l}\text { Ljubljansko } \\
\text { barje }\end{array}$ & 290 & 1922-1995+ & wet & 118 & & & 40 \\
\hline SI-GR & Grosuplje & 350 & 1929 & wet & 5 & 0 & 5 & \\
\hline & Nova & $300-600$ & & dry & 7 & 6 & 13 & \\
\hline & & 1100-1250 & $\begin{array}{ll}0 & 1\end{array}$ & dry & 0 & 1 & 0 & \\
\hline & & & & dry & 2 & 1 & 2 & \\
\hline & & & 201 & dry & 1 & 0 & 1 & 0 \\
\hline & & 250 & 2 & dry & 2 & 0 & 2 & 0 \\
\hline & $\mathrm{Ku}$ & 420 & 2012 & dry & 1 & 0 & 1 & 0 \\
\hline 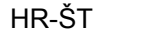 & & 250 & 2011 & dry & 2 & 0 & 2 & 0 \\
\hline & $\mathrm{Pr}$ & 200 & 201 & dry & 3 & 0 & 3 & 0 \\
\hline HR-SO & Sovinjak & 130 & 2007 & wet & 1 & 0 & & 0 \\
\hline
\end{tabular}

+ Years of collection: 1922, 1924, 1929, 1931, 1934-1938, 1941, 1949, 1961, 1968, 1969, 1971, 1979, 1980, 1984, 1992, 1995.

Appendix 3. Description of wing parameters used in the classical morphometric analysis of $C$. oedippus.

\begin{tabular}{|c|c|c|c|}
\hline Wing & Parameter abbr. (see Fig. 1) & Description & Unit \\
\hline \multirow[t]{9}{*}{ Forewing } & FWL1 & forewing length 1 (distance from forewing anchorage to termination of vein 8 ) & $\mathrm{mm}$ \\
\hline & FWL2 & forewing length 2 (distance from forewing anchorage to termination of vein 1 ) & $\mathrm{mm}$ \\
\hline & FWL3 & distance from forewing anchorage to inflection point & $\mathrm{mm}$ \\
\hline & FWL4 & distance from inflection point to the tip of forewing (termination of vein 8 ) & $\mathrm{mm}$ \\
\hline & FWL5 & distance from forewing anchorage to cubitus & $\mathrm{mm}$ \\
\hline & FWL6 & distance from cubitus to termination of vein 2 & $\mathrm{~mm}$ \\
\hline & FWH & forewing width (distance between terminations of veins 1 and 8 ) & $\mathrm{mm}$ \\
\hline & A & distance between termination of vein 3 and intersection between $\mathrm{FWH}$ and vein 3 & $\mathrm{~mm}$ \\
\hline & NFW & number of eyespots & \\
\hline \multirow[t]{16}{*}{ Hindwing } & HWL1 & distance from hindwing anchorage to inflection point & $\mathrm{mm}$ \\
\hline & HWL2 & distance from inflection point to the tip of hindwing (termination of vein 8) & $\mathrm{mm}$ \\
\hline & HWL3 & hindwing width (distance between the terminations of veins 8 and 2) & $\mathrm{mm}$ \\
\hline & HWL4 & distance from hindwing anchorage to the termination of vein 4 & $\mathrm{~mm}$ \\
\hline & HWL5 & distance from hindwing anchorage to the white centre of ocellus S6 & $\mathrm{mm}$ \\
\hline & HWL6 & distance from the white centre of ocellus $S 6$ to the termination of vein 8 & $\mathrm{~mm}$ \\
\hline & HWS & hindwing surface & $\mathrm{mm}^{2}$ \\
\hline & S1 & area of eyespot 1 & $\mathrm{~mm}^{2}$ \\
\hline & S2 & area of eyespot 2 & $\mathrm{~mm}^{2}$ \\
\hline & S3 & area of eyespot 3 & $\mathrm{~mm}^{2}$ \\
\hline & S31 & area of the black spot within the eyespot 3 & $\mathrm{~mm}^{2}$ \\
\hline & S4 & area of eyespot 4 & $\mathrm{~mm}^{2}$ \\
\hline & S5 & area of eyespot 5 & $\mathrm{~mm}^{2}$ \\
\hline & $\mathrm{S} 6$ & area of eyespot 6 & $\mathrm{~mm}^{2}$ \\
\hline & NHW & number of eyespots & \\
\hline & sums_hws & ratio: $(\mathrm{S} 1+\mathrm{S} 2+\mathrm{S} 3+\mathrm{S} 4+\mathrm{S} 5+\mathrm{S} 6) / \mathrm{HWS}$ & \\
\hline
\end{tabular}

